\title{
Access to Justice and the Challenges of Inter-Courts Transfer of Cases in Nigeria: The Way Forward
}

\author{
HON. JUSTICE OLUWAKAYODE OJO AROWOSEGBE \pm \\ Judge, National Industrial Court of Nigeria, 11, New Bussa Close, Area 3, Garki, Abuja
}

\begin{abstract}
This article interrogates the extent of access to justice in Nigeria on the premise that access to justice is indispensable to the attainment of a just and sustainable society. Drawing from international comparative sources, it posits that striking out of cases by courts in Nigeria on the basis of lack of jurisdiction makes mincemeat of the constitutional guarantee of right of access to justice. It examines the remedial efforts at curing this ill by the legislature through the grant of powers of inter-courts transfer of cases to superior courts in Nigeria. It investigates the negative impacts of the conflicting decisions of the nation's superior courts on these powers. It finds that failure to take cognizance of the distinctions between the hierarchies of Decrees and the Nigerian 1979 and 1999 Constitutions during military interregna and during civilian regimes, coupled with failure to appreciate the divergence between the extant constitutional provisions and the provisions of the defunct 1979 Constitution relied upon in the erstwhile cases, are a part of the causes of this problem; and that, the absolute inherent powers conferred on the superior courts by section 6(6)(a) of the extant 1999 Constitution, completes the other part. It establishes that, the powers could only be validly conferred and exercised during military interregna, but not under the present democratic constitutional framework; and that, until section 6 of the 1999 Constitution is altered, courts in Nigeria cannot validly exercise these powers. The work relies on both primary and secondary sources. The primary sources are made up of the Federal High Court Act, the National Industrial Court Act, the 1979 and 1999 Constitutions, and municipal judicial decisions. The secondary sources consist of journal articles, foreign decisions and statutes, newspapers, books and the Internet. The research adopts an analytical approach within a socio-legal context.
\end{abstract}

Keywords: access to justice, inter-courts transfer, jurisdiction, inherent powers, and sustainable society.

DOI: $10.7176 / \mathrm{JLPG} / 100-05$

Publication date:August $31^{\text {st }} 2020$

\section{INTRODUCTION}

The essence of judicial systems in modern democracies is to secure the right of access to justice for the people. This much is made clear by sections 6(6)(b) and 36(1) of the Constitution of the Federal Republic of Nigeria 1999 [1999 Constitution], which guaranteed the right of access to justice through the courts of the land. How far these provisions go in actually securing people's right of access to justice in Nigeria: that is, in having their grievances adjudicated upon in the courts of law, without being thrown out on the basis of want of jurisdiction, remains to be seen. For one, inabilities of courts in Nigeria to transfer cases over which they lack jurisdiction to the courts with competent jurisdiction appear to turn the intendment of these constitutional provisions completely into a mirage.

When a person's grievance could not be heard on the merits ${ }^{1}$, s/he could not be said to have had access to justice and neither could it be said, s/he has been given fair hearing ${ }^{2}$. This is so because; his/her case was not even heard at all. A case is only heard on the merits when both sides are afforded opportunities to state their respective cases before judgment is rendered. It is only when a case is heard on the merits that one can assess whether the hearing was fair or not. One, who is denied access to state his/her case, could not be said, to have received fair hearing.

In spite of the much-vaunted posture of the judicature in Nigeria that it will strive always to guarantee access to justice ${ }^{3}$, not much has been done in relation to constant restriction of people's right of access to justice by courts' inclination and constraint to striking out cases over which they lack jurisdiction. In reality, these occasion a denial of access to justice and in turn deny the nation the benefit of reaping the advantages of cases heard on the merits. Cases heard on the merits afford the judicature the opportunity of writing reasoned judgments, avoiding arbitrariness and facilitating rationalization of decisions. Consequently, these produce cathartic effects on the parties, which make the outcomes of cases more readily acceptable whereas, cases struck out on technicalities are

$\S$ The opinions expressed in this article are entirely my personal and private opinions.

\pm BA (Hons), LLB (Hons), BL (Hons), LLM, ChMC.

${ }^{1}$ See Western Steel Works Ltd. \& Anor. v. Iron and Steel Workers Union of Nigeria \& Anor. (1986) LPELR - 3479 (SC) p. 30, paras. B-F for the meaning of hearing a case on the merits. It is the litmus test by which the right of access to is measured throughout this treatise.

${ }^{2}$ Ayua, I.A., Ayua, I.A., ed. 'Nigerian Legal Profession and Prospects', in, Law, Justice and the Nigerian Society: NIALS Commemorative Series 1 (1995) (Nigerian Institute of Advanced Legal Studies, Lagos) at 6. See also N.U.T., Niger State v. COSST, Niger State [2012] 10 NWLR [Pt. 1307] 89 at 111, G-H; 113, D-E; 114, C. The Court of Appeal stressed the necessity of allowing people to ventilate their grievances in ordering the transfer of the case to the NICN with the requisite jurisdiction.

${ }^{3}$ Kalango v. the Governor of Bayelsa State \& Ors. (2009) LPELR - 1649 (SC) at. 14-15, paras. G-F. See also Fidelity Bank Plc v. Monye (2012) 10 NWLR (Pt. 1307) SC 1 at 32, E. 
incomprehensible to the losing parties in particular and the people in general. Consequently, they produce resentment against the judicature, which leads to disenchantment and resort to self-helps ${ }^{1}$. It is in this wise that, the Chief Justice of Canada, Rt. Hon. Justice McLachlin, P.C., admonished in very strong terms that, it is dangerous in the extreme for any society to encourage denial of access to justice ${ }^{2}$.

This research seeks to investigate the issue of 'substantive jurisdiction' in hearing cases on the merits versus 'procedural jurisdiction' in striking out cases for want of jurisdiction ${ }^{3}$. When a court comes to the conclusion in Nigeria that it lacks jurisdiction on a particular case, what then are the options available to it? One of the options is the transfer of such a case to a court with competent jurisdiction ${ }^{4}$. Another is to have the case struck out ${ }^{5}$. Yet, a third is for the court to continue with the case, even though, its jurisdiction has been ousted ${ }^{6}$. However, this research is strictly concerned with the first option, that is, 'inter-courts transfer of cases'. It argues that, much as Nigeria desires to curb the menace of striking out cases for want of jurisdiction by granting powers of inter-courts transfer of cases, there are no clear-cut principles in our case laws and statutes to guide the courts in making a choice; and that, even the right of inter-courts transfer of cases, as presently conferred and practised, is unconstitutional. Thus, we see our courts engaging in a vicious circle of macabre dance on this all-important matter of peoples' right of access to justice. It is against this backdrop that this research intends to critically examine the statutes, case laws and practices relating to 'inter-courts transfer of cases' in Nigeria. The research relied on both primary and secondary materials. The primary materials are the Federal High Court Act [FHCA], the National Industrial Court Act [NICA], the 1979 and 1999 Constitutions of Nigeria, and judicial decisions. The secondary materials are journal articles, books, foreign statutes and decisions, newspapers and the Internet.

\section{THE CHALLENGES OF INTER-COURTS TRANSFER OF CASES 2.1 Historical Perspectives}

Traditionally, a court that lacks jurisdiction on a case lacks the power to make any order on the matter, except an order striking out the case ${ }^{7}$. This is a derivative of Common Law ${ }^{8}$. Common Law came into Nigeria in the era of over reliance on technicality ${ }^{9}$, which placed premium on the adversarial system of litigation with its technicalities ${ }^{10}$ without minding the harshness or injustice that might arise therefrom ${ }^{11}$. As time went on, people increasingly became disenchanted with technical justice ${ }^{12}$. In response, the judiciary and the legislature made attempts to temper the rigour of technical justice ${ }^{13}$. One of the areas where the injustice of technicality or the harshness of Common Law manifested itself most was in the area of cases being struck out for lack of jurisdiction.

The irony is that, often, most of the cases struck out were actually filed in the appropriate courts at the times when such courts had the requisite jurisdictions to entertain them ${ }^{14}$. In the course of hearing or before they were heard to conclusion, statutes were enacted, divesting the courts of jurisdiction ${ }^{15}$. Notwithstanding the fact that it

\footnotetext{
${ }^{1}$ Udombana, N.J., Azinge, E. and Adekunle D. eds., 'Access to Justice and Judicial Attitude to Standing in Nigeria', in Administration of Justice and Good Governance in Nigeria (2011), Nigerian Institute of Advanced Legal Studies, Lagos) at 283-322. See also Davidson Iriekpen, 'Dispute Resolution: Making a Case for ADR' in THISDAY Newspaper, Vol. 16, No. 5826 of Wednesday, April 6, 2011, p. 24, wherein it was reported that a party who actually won a case of wrongful dismissal, after a protracted 9-year trial, expressed frustration and disappointment at the nature of justice in our courts. How much more, a plaintiff, whose case was struck out for want of jurisdiction after 23 years? And come to think of it, it was not the fault of the plaintiff that the court was divested of jurisdiction mid-way into his case. Nonetheless, he was sent away from the temple of justice empty-handed, just like that! Such was the fate of the plaintiff in Obiuweubi v. CBN (2011) 7 NWLR (Pt. 1247) 465; (2011) LPELR - 2185 (SC).

${ }^{2}$ The Right Honourable Beverley McLachlin, P.C., Chief Justice of Canada - in 'Supreme Court of Canada - Beverley Mclachlin' at http://scccsc.gc.ca/court-cour/ju/mclachlin/index-eng.asp accessed on 20/06/13.

${ }^{3}$ Nagogo v. CPC \& Ors (2012) LPELR-15521 (SC) 26-27, E-C.

${ }^{4}$ Omisade v. Akande (1987) LPELR - 2639 (SC); (1987) 2 NWLR (Pt. 55) 158.

${ }^{5}$ Obiuweubi v. CBN op. cit.

${ }^{6}$ Othopaedic Hospitals Management Board v. Garba \& Ors (2002) LPELR - 2775 (SC).

${ }^{7}$ Dangana \& Anor. v. Usman \& Ors. (2012) LPELR - 7827 (SC) 35 - 36, G-A; and Obi v. INEC \& Ors. (2007) LPELR - 2166 (SC) 30, AC.

${ }^{8}$ Fasakin Foods (Nig.) Ltd. v. Shosanya (2006) LPELR - 1244 (SC) 29, A-B.

${ }^{9}$ Technicality is used here in the sense of deciding cases on issues extrinsic to hearing the cases on the merits. Jurisdictional question is one of such issues because it is extrinsic to the merits of cases.

${ }^{10}$ Broad Bank Nigeria Ltd. v. S. Olayiwola \& Sons \& Anor. (2005) LPELR - 806 (SC).

${ }^{11}$ Ayua, I.A., Ayua, I.A., ed., 'Nigerian Legal Profession: Problems and Prospects', op. cit. at 6. See also Obiuweubi V. CBN op. cit., which took 23 years for the judicature to decide which court had jurisdiction between the FHC and the High Court of Lagos State. At the end, the Supreme Court struck out the suit for want of jurisdiction on the part of the trial Court!

${ }^{12}$ Vanderbilt, J.A., The Challenge of Law Reform, (1955), Princeton University Press, Princeton, at 4-5.

${ }^{13}$ The movement away from technical justice to substantial justice is still on; and is the cause of the increasing popularity of Alternative Dispute Resolution [ADR] Mechanisms globally.

${ }^{14}$ Obiuweubi v. CBN (supra), which was commenced long before the State High Court was divested of portions of its jurisdiction in favour of the FHC.

${ }^{15}$ Federal Revenue Court Act, 1973; Decree No. 107 of 1993; and the Constitution of the Federal Republic of Nigeria (Third Alteration) Act, 2010 [Third Alteration Act]. The first and second statutes divested the High Court of a State parts of its hitherto jurisdiction and gave exclusive jurisdiction over those aspects to the Federal Revenue Court, which later became the Federal High Court [FHC]. In the same manner, the Third Alteration Act also divested both the FHC, the High Court of a State, and the High Court of the FCT, Abuja [FCT High Court] of parts of their hitherto jurisdictions and ceded them exclusively to the National Industrial Court of Nigeria [NICN].
} 
was not the fault of the plaintiffs that their matters were not heard or heard to conclusion before the ouster of the court's jurisdiction, the cases had to be struck out any way, for want of jurisdiction on the part of the courts ${ }^{1}$. Attempts to re-file them at the appropriate courts were also thwarted again by another technicality in the name of 'statute of limitation'2 or 'statute bar', which does not stop running ${ }^{3}$ simply because the initial courts were divested of jurisdiction mid-way into the cases. In effect, it was as if the law deliberately set out to make some people unlucky through no fault of theirs ${ }^{4}$. Equally significant are the devastating rigmaroles of determining which court has jurisdiction, which often drag on for unreasonably long time, such that, in most cases, the plaintiffs die before the issues of jurisdiction are resolved or the subject matters of the suit are totally exhausted so that, if eventually their cases are heard on the merits and they win, they only have pyrrhic victories ${ }^{5}$ These obviously are unmitigated injustices that ought not to exist in modern societies with all the touted sophistications - unwarranted restrictions of people's right of access to justice: monumental epitomes of injustice. No civilized nation can continue to fold its arms in a situation like this without inviting chaos. The same goes for cases simply filed in the wrong courts, either as a result of non-clarity as to which court has jurisdiction over the subject matter ${ }^{6}$ or just out of ignorance. It is felt the right of people to access courts and invariably, justice, should not just be abridged without very good reasons. And that, even if a matter is filed in the wrong court ab initio, avenue should be created to allow the wrong court send the case to the appropriate court, instead of just striking it out to be caught with statute of limitation. It is also felt that, striking out will be unjust since there exist courts with the requisite jurisdiction in the nation ${ }^{7}$.

In apparent appreciation of the above, the first attempt at conferring a court in Nigeria with the abatement power to transfer a matter over which it lacks jurisdiction to the court with the requisite jurisdiction was the enactment of section 22(2) of the Federal Revenue Court Decree No. 13 of 19738:

"No cause or matter shall be struck out by the Federal Revenue Court merely on the ground that such cause or matter was taken to the Federal Revenue Court instead of the High Court of a State in which it ought to have been brought and the Judge of the Federal Revenue Court before whom such cause or matter is brought may cause such cause or matter to be transferred to the appropriate High Court of a State in accordance with the rules of court to be made under section 43 of this Decree."

Decree No. 13 of 1973 did not provide for bilateral right of the High Court of a State to transfer cases over which it did not have jurisdiction but on which the Federal Revenue Court [FRC] had jurisdiction, to the FRC. As is expected, attempts of the High Court of a State to transfer such cases to the FRC based on section 22(2) of Decree No. 13 of 1973 was resisted. Expectedly, the Supreme Court held that the High Court of a State could not, without an enabling statute in that behalf, transfer cases to the Federal High Court [FHC $]^{9}$. This necessitated an amendment to Decree No. 13 of 1973, which culminated in Decree No. 36 of 1975 [later Act], by which subsection (3) was added to section 22 of Decree No. 13 of 1973 to cure this defect. Section 22(3) of the Federal Revenue Court Act, 1975 [FRCA], which later became the Federal High Court Act [FHCA], in its remedial efforts, provides:

"Notwithstanding anything to the contrary in any law, no cause or matter shall be struck out by the High Court of a State on the ground that such cause or matter was taken in the High Court instead of the Federal Revenue Court, and the Judge before whom such cause or matter is brought may cause such cause or matter to be transferred to the appropriate Judicial Division of the Federal Revenue Court in accordance with such rules of court as may be in force in that High Court or made under any enactment or Law empowering the making of rules of court generally, which enactment or law shall by virtue of this subsection be deemed also to include power to make rules of court for the purposes of this subsection."

Ever since, the FRC, which later metamorphosed into the FHC, has retained these provisions ${ }^{10}$. In 2006 the

\footnotetext{
${ }^{1}$ Obiuweubi v. $C B N$ (supra).

${ }^{2}$ The implication of upholding the order of striking out in Obiuweubi $V$. CBN (supra) by the Supreme Court on the $11^{\text {th }}$ March, 2011 was that the case could not be re-filed at the appropriate Court as limitation laws, which usually prescribed 5 or 6 years, would have caught it - see s. 20 of the Actions Law of Enugu State, CAP. 4, Laws of Enugu State 2004, which prescribed 5 years; and section 7 of the Limitation Act, Cap. 522, Vol. 3, Laws of the Federation of Nigeria (Abuja), which prescribed 6 years.

${ }^{3}$ Ajani \& Ors. v. Taiwo (2011) LPELR - 3669 (CA) at 11, paras. C-D.

${ }^{4}$ Echelukwo John O. \& 90 Ors. v. Igbo-Etiti Local Government Area, Suit No. CA/E/261/2011, delivered by the Court of Appeal, Enugu Division, on the $10^{\text {th }}$ day of December, 2012 p.12, where this same problem was identified.

${ }^{5}$ Obiuweubi v. $C B N$ (supra), which took 23 years to determine the Court with competent jurisdiction.

${ }^{6}$ Ediru, M., 'The Continuing Reverberation of the Existing Approach to Determining the Exclusive Jurisdiction of the Federal High Court' in Nigerian Bar Journal (2011) Vol. 67, No. 1, August 2011 at 1 -30. It discussed the recondite nature of determining the frontiers of the exclusive jurisdiction of the FHC, and submits that, this is the cause of cases been filed in the wrong courts.

${ }^{7}$ Echelukwo John O. v. Igbo-Etiti Local Government Area (supra).

${ }^{8}$ Decree No. 13 of 1973 [later Act].

${ }^{9}$ Williams v. Attorney-General of the Federation (1975) SC, (1975) LPELR - 3485 (SC) 14-15, B-E.

${ }^{10}$ S. 22 (2) \& (3) of the FHCA, 1973 [as amended in 2005].
} 
NICA $^{1}$ followed suit when, in its section $24(2) \&(3)$, it made identical provisions as those of the FHCA on matters relating to inter-courts transfer of cases. Like the FRC, which later became the FHC, the National Industrial Court ${ }^{2}$ [NIC] later became the National Industrial Court of Nigeria $^{3}$ [NICN]. The NICN was made a superior Court of record pursuant to section 6(5)(cc) of the 1999 Constitution [as altered]. And by virtue of sections 315(a) and $316(5)$ of the 1999 Constitution [as altered], the NICA is preserved. In effect, the provisions of section 24(2) \& (3) of the NICA, conferring the powers of inter-courts transfer of cases on the NICN and the other courts of coordinate jurisdiction ${ }^{4}$ in Nigeria, are saved and, they are meant to continue to have effect in accordance with their tenor. Right away from 1973 to 1975 when the FRCA and its subsequent amendment directly attempted to whittle down the negative effects of inability of courts to transfer cases over which they lack jurisdiction to the appropriate courts, to the attempt in 2006 by the NICA, these attempts have been enmeshed in controversies, with divergent decisions issuing from the superior courts of the land, such that, the purposes of these legislations are either being totally frustrated or not being fully realized, at the least. Such was the speed with which the controversies arrived that, as early as 1975, the Supreme Court of Nigeria had handed down a decision on this issue ${ }^{5}$. A discussion of these controversies follows.

\subsection{Critical Analysis of Powers of Inter-Courts Transfer of Cases in Nigeria}

'Inter-Courts transfer of cases', as distinct from 'intra-court transfer of cases', is the procedure whereby a court exercises abatement power to transfer cases filed before it, over which it lacks jurisdiction, to another independent and separate court, which is seised of jurisdiction in the cause. This is in contradistinction to intra-court transfer of cases'. 'Intra-court transfer of cases', on the other hand, is the transfer of cases within various divisions of the same court. It is a matter of discretion within the powers of the head of such a court ${ }^{6}$. And it hardly elicits any controversy $^{7}$, as the Law and Rules of each court invariably provide for this ${ }^{8}$. Primarily, the exercises of powers of inter-courts transfer of cases are between superior courts of co-ordinate jurisdiction in Nigeria. The appellate courts - the Court of Appeal and the Supreme Court - only partake of these powers in their appellate exercise of powers 9 .

The laws and practices relating to the powers of courts to transfer cases over which they lack jurisdiction have always been trailed by controversies in Nigeria. And these have become accentuated in recent time by the enactment of the Constitution of the Federal Republic of Nigeria (Third Alteration) Act 2010 [Third Alteration Act], which made the NICN a superior Court of record and vested it with exclusive jurisdiction over all employment and labour relations matters. This has reinforced the provisions of section $24(2) \&$ (3) of the NICA, which grant power of inter-courts transfer of cases between the NICN and other courts of co-ordinate jurisdiction in Nigeria. At one side of the fray is the convoluted ${ }^{10}$ decision of the Supreme Court in Aluminium Manufacturing Company (Nigeria) Ltd. v. Nigeria Ports Authority ${ }^{11}$. This case decided, it will seem ${ }^{12}$ that, based on section 22(2) \& (3) of the FHCA, in conjunction with sections 230, 231 and 233 of the 1979 Constitution that, while the FHC can transfer cases to the High Court of a State, the High Court of a State would not enjoy the same liberty of bilateral power to transfer cases to the FHC. The brief facts of the case are, the plaintiff, now appellant, commenced the suit at the FHC, Lagos Division. The claim was for $\$ 198,872.99$ general and special damages with interest at the rate of $10 \%$ per annum, for breach of a contract of bailment and or breach of duty as a bailee, on 47 packages of aluminium sheets delivered to the defendant, now respondent, which got lost in the defendant/respondent's custody.

Objection, as usual ${ }^{13}$, was raised by the defendant/respondent in limine ${ }^{14}$ to the jurisdiction of the FHC to

\footnotetext{
${ }^{1}$ Federal Republic of Nigeria Official Gazette No. 38, Lagos $16^{\text {th }}$ June, 2006.

${ }^{2}$ S. 1 of the NICA.

${ }^{3}$ See s. $254 \mathrm{~A}-(1)$ of the 1999 Constitution as altered by s. 6 of The Third Alteration Act.

${ }^{4}$ That is, the FCT High Court and the High Court of a State.

${ }^{5}$ Williams v. Attorney-General of the Federation (supra), which was decided on Thursday the $24^{\text {th }}$ April, 1975 . See also Mokelu v. Federal Commissioner for Works and Housing LER (1976) SC 140/1975; (1976) 3 SC (REPRINT) 60, which was delivered on Friday the $19^{\text {th }}$ March, 1976.

${ }^{6}$ Dike \& Ors. v. Aduba \& Ors. (2000) LPELR - 944 [SC] 12, A-C.

${ }^{7}$ But evidence of improper motive for exercising the power might vitiate it - see Zakari v. The State (2008) 10 NWLR (Pt. 1096) CA 112 - 13, G-E; Balonwu v. Obi (2007) 5 NWLR (Pt. 1028) CA 488 at 530-531, D-A, 544-545 paras. H-E; and O.L.G.C. v. A.I.S.H.A. (2008) 3 NWLR (Pt. 1075) CA 502 at 516-517, F-A

${ }^{8}$ Folagbade \& Anor. v. Governor of Ondo State \& Ors. (2007) LPELR - 4227 (CA) at 25-29, paras. G-D

${ }^{9}$ Ss. $22(5) \&(6)$ and 24 (5) \& (6) of the FHCA and the NICA respectively.

${ }^{10}$ This decision contains self-contradictory rationes, such that, it is difficult to say precisely what the decision is, on the powers of the High Court of a State to transfer cases to the FHC.

${ }^{11}$ (1987) LPELR - 438 (SC).

12 This phrase is employed because subsequent holdings of the Supreme Court in the same case stands, with respect, in direct contradiction to the holding that the High Court of a State cannot transfer cases to the FHC.

${ }^{13}$ Capitalising on technicalities, hardly does a suit proceed to hearing on the merits in Nigeria without an objection being raised as to the competence of the court to try the suit. Often, valuable times are wasted on these wild-goose chases.

${ }^{14}$ Bryan A. Carner ed., Black's Law Dictionary, (Ninth Ed.) at 858 for "in limine" or "in-limine"; and p. 939 for "limine"; the terms all mean
} 
entertain the matter on the ground that the claim, as framed, did not fall within the admiralty jurisdiction of the FHC. The argument was that, the mere fact that the defendant, the Nigerian Ports Authority, being a port owner or being a shipping authority, did not make the claim an admiralty claim, the claim being an ordinary bailment claim, which did not fall within the admiralty jurisdiction of the FHC. That is, admiralty jurisdiction of the FHC ends immediately goods are discharged and loaded off ships to the warehouses or on the grounds. The defence counsel urged the court to strike out the matter. The plaintiff's counsel argued in opposition that, the matter should be transferred to the Lagos State High Court instead of its being struck out, in the event of the court upholding the objection. The plaintiff's counsel authorities for this proposition were to be found in section 22(2) \& (3) of the FHCA 1973 [as amended] as purportedly validated by sections 230, 231 and 233 of the Constitution of the Federal Republic of Nigeria, 1979 [1979 Constitution].

After a careful consideration of the arguments of counsel, the FHC upheld the objection that it lacked jurisdiction to entertain the matter. However, it disagreed with the prayer that the matter be struck out, and instead, transferred it to the Lagos State High Court, as canvassed by the counsel to the plaintiff. Being dissatisfied, the defendant appealed to the Court of Appeal. In deciding the appeal, Adenekan Ademola, JCA, held:

"It is not the intention of the Constitution that a court of co-ordinate jurisdiction which the Federal High Court is to the State High Court should interfere in matters of practice and procedure of which transfer of a case from one court to another is. The order of transfer here is invalid and whatever is contained in the Federal High Court Act in justification of that transfer is void and of no effect whatsoever ${ }^{1}$."

Based on the above reasoning, the Court of Appeal found for the defendant/appellant and struck out the suit. Being dissatisfied, the plaintiff/respondent appealed to the Supreme Court. The Supreme Court, in setting aside the decision of the Court of Appeal and holding to the contrary that the FHC's power to transfer cases on which it lacks jurisdiction remains sacrosanct, stated:

"The question that arises in this matter is whether there is power in a State High Court, in this case, Lagos State High Court to transfer a matter which it has no jurisdiction to entertain. The clear answer is in the negative in such cases, the order it has power to make is an order striking out the matter... However, the express provision of section 230(2) of the Constitution giving the court the powers the Federal Revenue Court had under section 22(2) and which the State High Courts have under section 22(3) of the Federal Revenue Court Decree supersede and nullify the provision of Order 22 Rule 3 of the High Court of Lagos State Civil Procedure Rules in relation to the question of transfer after upholding a plea to the jurisdiction of the court. Since the Federal Revenue Court had power to transfer a matter in respect of which it had no jurisdiction to a State High Court, the Federal High Court, which is the Federal Revenue Court under a new name continues to have the power to transfer ${ }^{2}$."

The decision of the Supreme Court herein sets down the principle of law that the FHC has an unfettered power to transfer cases over which it lacks jurisdiction to the State High Court. It also appears to have held that the High Court of a State has no corresponding power to transfer cases vice versa. But this aspect of the rationes is shrouded in ambiguity. When one considers the very first and the second sentences, as quoted above, they show clearly that the Supreme Court held that the State High Court could not transfer cases to the FHC. However, when one considers the subsequent holdings in the same decision, then, it becomes doubtful whether the Supreme Court actually meant that the High Court of a State could not transfer cases to the FHC. For, what is the implication of the subsequent holding, that is, the second to the last sentence of the excerpt? Obviously, a literal construction is that, the High Court of a State equally has the power to transfer cases to the FHC. If section 230(2) of the 1979 Constitution nullified Order 22, Rule 3 of the High Court of Lagos State (Civil Procedure) Rules, as the Supreme Court held, it follows logically that nothing then stopped the High Court of Lagos State from exercising the power to transfer to the FHC. This much is confirmed in the concurrent judgment of Karibi-Whyte JSC:

"It seems to me that a Judge in the Lagos State High Court cannot, without relying on the provisions of section 230(2) of the Constitution, instead of dismissing an action for want of jurisdiction exercise powers under Order 22 r. 3 of the Lagos State High Court (Civil Procedure) Rules, to transfer the matter to another Court...This section which is an existing law could be relied upon in such situations. This power is vested in the State High Courts by the Constitution and not as the Court of Appeal erroneously thought by virtue of the Federal High Court Act, $1979^{3} . "$ [Italics for emphasis]

From the above, it will appear certain that, what the Supreme Court is saying is that, the High Court of Lagos State could not rely on the provisions of the Lagos State High Court Rules in question, which, in any case, did not

raising a point of law to be determined preliminarily without going into the merits of a case.

${ }^{1}$ Aluminium Manufacturing Company (Nigeria) Ltd v. NPA [supra], 34, B-C, 36 - 37, G-A.

2 Ibid, 24-25, D-G.

${ }^{3}$ Ibid, $41-44$, A-B 
provide for inter-courts transfer of cases but actually for dismissing cases over which the Court had no jurisdiction, to transfer cases to the FHC, but could competently rely on section 230(2) of the 1979 Constitution, which it says, incorporated section 22(3) of the FHCA to empower both the High Court of a State and the FHC to exercise bilateral powers of transfer of cases inter se. Nonetheless, as observed by the Supreme Court itself, the issue of whether the Lagos State High Court could transfer cases to the FHC did not actually arise in the case ${ }^{1}$. What came before the Court was: whether the FHC could transfer cases to the High Court of a State. So, the aspect of the decision on State High Court's power to transfer cases to the FHC was, in essence, an obiter dictum ${ }^{2}$. Therefore, it is strange how this decision has been cited as firmly deciding that the High Court of a State cannot transfer cases to the $\mathrm{FHC}^{3}$. Aluminium Manufacturing Company v. NPA [supra] is quoted extensively because, as will be seen later, it is the sheet anchor, on which all the subsequent decisions on the issue of whether or not the High Court of the State can transfer cases to the FHC and vice versa, are based. It is either a subsequent decision, in essence, agrees with it or not. However, in Omisade v. Akande ${ }^{4}$, which was decided earlier on $10^{\text {th }}$ April, 1987, as against Aluminium Manufacturing Company v. NPA [supra] that was decided later on $21^{\text {st }}$ July, 1987, the Supreme Court firmly held that, the High Court of a State has the power to transfer cases to the FHC:

"In exercise of the general powers of this Court under section 22 of the Supreme Court Act, 1960 of having "full jurisdiction over the whole proceedings as if the proceedings had been instituted in the Supreme Court as a court of first instance", I order that the cause, i.e. the plaintiff's claim, be transferred to the Federal High Court, Lagos which as per section 230(2) of the Constitution of the Federal Republic of Nigeria 1979 replaced the Federal Revenue Court for hearing de novo."

The Supreme Court reconfirmed itself subsequently on the same issue in Associated Discount House Ltd. v. Amalgamated Trustees $L t d^{6}$. This later decision, which was delivered on $5^{\text {th }}$ May 2006, was again based squarely on section 22(3) of the FHCA. But it must be noted that, again, the Court observed that, the issue was not even necessary ${ }^{7}$. This again meant that, the decision was an obiter dictum. This is because, the case was transferred from the FHC to the Lagos State High Court, which the Supreme Court found to have jurisdiction. In the two instances, the Supreme Court, with the greatest respect, did not appear to give any in-depth consideration of the matter and; in addition, the Supreme Court did not advert its mind to section 239 of the 1979 Constitution, which gave the House of Assembly of a State the power to make laws for the High Court of a State, which section 22(3) of the FHCA conflicts with, and also the earlier decisions of the Court to the contrary ${ }^{8}$. It is therefore not surprising that the same Supreme Court, had earlier on, in the same year, held the direct opposite in Fasakin Foods [Nig.] Ltd. v. Martins Babatunde Shosanya ${ }^{9}$. Fasakin's case was decided on the $28^{\text {th }}$ of April, 2006 on the direct issue of whether the High Court of a State had the power to transfer cases over which it lacked jurisdiction to the FHC as against Associated Discount House Ltd. v. Amalgamated Trustees Ltd which was decided on the $5^{\text {th }}$ of May, 2006; and the Supreme Court unambiguously held in Fasakin's case that:

"Unless and until there is a clear enabling provision in the Lagos State High Court Law or the State High Court (Civil Procedure) Rules empowering the State High Court to exercise the powers vested in it under section 22(3) of the Federal High Court Act not being a law made by the House of Assembly of the State pursuant to section 239 of the 1979 Constitution, the trial Court has no power to transfer the appellant's action wrongly filed in that court to the Federal High Court, Lagos Judicial Division ${ }^{10}$."

It is necessary to note that the decision of the Supreme Court in Fasakin's case was a decision of the 'Full Panel' ${ }^{11}$ of the Supreme Court, where this issue fell directly for determination and was comprehensively considered. It is also necessary to note that the decision, in part, upheld the reasoning of the Court of Appeal in Aluminium Manufacturing Co. (Nig.) Ltd v. NPA [supra]. It is therefore already evident that, there is conflict in the apex Court's decisions as to whether a State High Court has the power to transfer a case to the FHC. As to the power of the FHC to transfer cases to the High Court of a State, the consensus of Supreme Court's decisions is that, the FHC can competently transfer to the High Court of a State.

\footnotetext{
${ }^{1}$ Ibid, 43, D-F.

${ }^{2}$ Bamgboye v. University of Ilorin \& Anor. (1999) LPELR - 737 (SC) 31, D-E; (1999) 10 NWLR (Pt. 622) 290.

${ }^{3}$ Few examples are: Fasakin Foods (Nig.) Ltd. v. Shosanya (supra); Amalgamated Trsutees Ltd. v. Associated Discount House Ltd. (2006) LPELR - 583 (SC); and Believers Fisheries Dredging \& Anor. V. U.T.B. Trustees Ltd. (2010) LPELR - 3864 (CA). 


\subsection{Clarification of the Conflicts in the Supreme Court's Decisions}

The Supreme Court had the opportunity to examine the conflict in its decisions relating to the power of the High Court of a State to transfer cases over which it lacks jurisdiction to the FHC in Amalgamated Trustees Limited $v$. Associated Discount House Limited ${ }^{1}$, which was decided on $13^{\text {th }}$ July 2007. In it, the Supreme Court appeared to say that, in effect, its decision in Associated Discount House Ltd. v. Amalgamated Trustees Ltd [supra] was decided per incuriam; since it says its attention was not drawn to its previous contrary decisions on the same issue ${ }^{2}$. And if the decision is per incuriam ${ }^{3}$, then, it cannot be a good authority or at least, the last has not been heard on the issue. Since it is the Supreme Court itself that declared its previous decision per incuriam then, the decision declared to be arrived at per incuriam is not binding on the lower courts, having been overruled.

It needs also to be pointed out that Amalgamated Trustees Limited v. Associated Discount House Limited [supra] is an application to have the Supreme Court set aside its decision in Associated Discount House Ltd. v. Amalgamated Trustees Ltd [supra], so the issue of transfer was not a live one before the Supreme Court. Investigations have not revealed any further decision of the Supreme Court on this burning issue later than the above. And since this ratio emanates from a later Supreme Court's decision, it means that the lower courts are bound by its holding that the High Court of a State cannot transfer cases to the FHC. This is because the latest in time, amongst Supreme Court's conflicting decisions, prevails ${ }^{4}$. More so, the Supreme Court's decision on the direct question of whether the High Court of a State can transfer cases to the FHC in Fasakin Foods (Nig.) Ltd. v. Martins Babatunde Shosanya [supra] remains valid in view of the fact that it remains the latest amongst the authorities of the Supreme Court that directly considered and held that the High Court of a State cannot transfer cases to the FHC. The other cases, including Associated Discount House Ltd v. Amalgamated Trustees Ltd [supra], as shown earlier, were decided, on this vexed issue, in obiter $^{5}$. And an obiter dictum is not binding on the lower courts, with the greatest respect, even if from the Supreme Court ${ }^{6}$, notwithstanding the dictum of Nnaemeka-Agu to the contrary in Ifediorah v. Ume ${ }^{7}$.

Even though, it has been shown that the position now is that the State High Court has no power to transfer to the FHC, but the fact remains that, this is arrived at by a process of reasoning through a welter of cases that are, in most cases, not by any means very clear on the matter, except Fasakin's case [supra]. Thus, it goes without any equivocation that, the position of law today as regards whether the High Court of a State can transfer cases to the FHC remains hazy. This area creates a recondite point of law, which is yet to be finally rested. To this considerable confusion and the attendant difficulty has been added, the problem of deciding the powers of transfer between the NICN, the FHC, the Federal Capital Territory High Court [FCT High Court] and the High Court of a State; arising from the recent conferment of exclusive jurisdiction on all employment and labour relations matters on the NICN.

\subsection{Examination of the Practice of Inter-Courts Transfer Under Section 24 of the National Industrial Court Act}

The recent decision of the Court of Appeal in relation to section 24(3) of the NICA has, in earnest, reinforced the recondite nature of this issue, setting in motion, in quick succession to the Third Alteration Act, another vehicle of controversy. In Echelukwo John O. \& 90 Ors. v. Igbo-Etiti Local Government Area ${ }^{8}$ the Court of Appeal accentuated the problem in the following words:

"Following the enactment of the Constitution (third (sic) Alteration) Act, 2010 which gave exclusive jurisdiction to the National Industrial Court on Labour [sic] matters, both the State and Federal High Courts, including that of the Federal Capital Territory, Abuja ceased to have jurisdiction in those matters pending before them. If they are struck out and there is need to file them afresh, some of them may be caught by statute of limitation and the plaintiffs in such

\footnotetext{
1 (2007) 15 NWLR (Pt. 1056) 118.

${ }^{2}$ Ibid, $147, \mathrm{C}-\mathrm{G}$.

${ }^{3}$ Makun \& Ors. v. Federal University of Technology, Minna (2011) LPELR - SC.241/2002. See also Buhari v. INEC (2008) LPELR - 814 (SC); and Asanya v. State (1991) LPELR - 574 (SC) 31, A-G.

${ }^{4}$ Opene v. NJC \& Ors. (2011) LPELR - 4795 (CA) 48 - 49, F-A; Kofa \& Anor v. Kaita \& Ors. (2011) LPELR - 8952 (CA) 96, B-C.

${ }^{5}$ In Associated Discount House Ltd. v. Amalgamated Trustees Ltd (supra), the Supreme Court specifically held at 15, D-E that “... but that is not relevant in the case here"; being that the court to exercise the power was the FHC and so, the live issue was whether the FHC could transfer to the High Court of a State.

${ }^{6}$ See Afro-Continental Nigeria Ltd. v. Ayantuyi (1995) LPELR - 218 (SC) 37, E-F

${ }^{7}$ (1988) LPELR - 1434 (SC)12-13, E-A. The authority of Nnaemeka-Agu for the dictum was rooted in the House of Lords' decision, which are not binding on courts in Nigeria. More so, Afro-Continental case, which is subsequent to Ifediorah's case, re-emphasized the mantra that an obiter is not binding on any court. A close study of Buhari v. Obasanjo (2003) LPELR - 813 (SC) 66, B-D, where the dictum of Edozie, JSC seems to re-echo the bindingness of obiter dicta of Supreme Court on lower courts, will reveal that what Edozie, JSC actually meant is that such Supreme Court's obiter is persuasive authority to lower courts. This is evident if one considers p. 65-66, G-A, which preceded the dictum in issue and the dictum of Belgore, JSC at p. 18, E-F of the same case, which together hold that, an obiter, has no binding effect. The fog on this issue was finally laid to rest in Nwana v. FCDA \& Ors. (2004) LPELR - 2102 (SC) 12-13, G-A, where Tobi, JSC stated emphatically that an obiter of the Supreme Court is not binding but has persuasive force only; and that, it might only assume the status of a rationes decidend if it has been acted upon repeatedly by courts.

${ }^{8}$ Suit No. CA/E/261/2011, delivered by the Court of Appeal, Enugu Division, on the $10^{\text {th }}$ day of December, 2012.
} 
situation, without fault of theirs, would suffer grave injustice. It became necessary to make such provisions as section 24(3) of the National Industrial Court Act in order to preserve such suits and to be transferred to the National Industrial Court for proper adjudication. When the learned trial judge stated in his judgment that he is not bound by section 24(3) of the National Industrial Court Act, I am not sure he knew what he was saying. This is an Act of the National Assembly and no court can say he is not found (sic) by its provisions. I wonder what the learned trial judge wanted before he could simply order the matter to be transferred ${ }^{1} . "$ [Italics for emphasis]

This matter was originally filed at the High Court of Enugu State when it still had jurisdiction on the subject matter, but its jurisdiction was ousted mid-way into the case by the Third Alteration Act, which came into force on $4^{\text {th }}$ March 2011. Consequently, the High Court of Enugu State struck out the matter. The Court of Appeal, in reversing the order of striking out made by the trial High Court, castigated the trial judge for holding that he was not bound by section 24(3) of the NICA, which gives the High Court of a State power to transfer suits to the NICN. Though, one is not privileged to see the reasoning by which the trial Court arrived at its decision, as this was not stated by the Court of Appeal, but the fact remains that, the Court of Appeal, with all due respect, appears hasty in chastising the trial Judge. This is more so when the Court of Appeal itself did not give any better reasons for its decision other than merely interpreting the imperative dictates of the word "may" in the context of its usage in section 24(3) of the NICA and that, courts in Nigeria must be bound by all Acts of the National Assembly. It did not itself cite any authority from the Supreme Court or any of its previous decisions on the matter to show that it appreciated the complexity of the problem. And yet decisions abound on this issue! The idea trumpeted that, because the NICA is an Act of the National Assembly it is automatically binding on all courts in Nigeria is, with the greatest respect, erroneous.

With the ascendance of democracy and the 1999 Constitution, which has clearly delineated the frontiers of legislative competences of both the House of Assembly of a State and the National Assembly, the validity of any enactment from either of the two tiers of legislature is to be tested against the enumerated list of spheres of legislative competences created by the 1999 Constitution. The perfunctory approach adopted by the Court of Appeal in arriving at this grave decision is, with due respect, rather too simplistic an approach, in that, it does not appreciate the constitutional questions involved in a federal State like Nigeria. One may hazard then, that, if the Court of Appeal had adverted its mind to previous decisions, its own ${ }^{2}$, and particularly those of the Supreme Court $^{3}$, on this issue, it would most probably not have descended so heavily on the trial Judge, whose view obviously seemed backed up by more authorities than that of the Court of Appeal, even if it would still have overruled Him. It is likely that the last has not been heard on this case, if the respondent decides to appeal to the Supreme Court, since the case emanated from the High Court of State. Thus, the NICA may be in to have its own full dose of conflicting decisions on whether the High Court of a State can transfer a case to the NICN. To this might be added the additional factor of the FCT High Court. What is responsible for this state of affairs is the relative interpretation given to the relationship between the Federal Government and the federating units, that is, the states. This is the sheet anchor of the divergent decisions. And the merits and demerits of the decisions can be located within this benchmark.

\subsection{Federalism and Implications for Inter-Courts Transfer of Cases in Nigeria}

At one length, courts are of the opinion that States of the Federation and their organs or agencies, being independent components and separate entities from the Federal Government and its organs, cannot be imposed upon by the Federal Government or any of its organs in ways not clearly provided for by the 1979 Constitution and ipso facto, the 1999 Constitution [as altered]. On the other hand, courts are also of the contrary opinion that, the Constitution itself validated the provisions allowing both the FHC and the High Court of a State to transfer matters inter se. These two opposing postulations therefore deserve critical examination.

It is proposed to begin with the argument that the Federal Government, albeit through the National Assembly, cannot impose obligations on the Federating Units and their agencies. The genesis of this argument can be traced to the Court of Appeal's decision in Aluminium Manufacturing Co. Ltd. v. N.P.A. [supra], wherein Ademola JCA held that under the 1979 Constitution, it was unconstitutional for courts to exercise the powers of inter-courts

\footnotetext{
${ }^{1}$ At 12 .

${ }^{2}$ Believers Fisheries Dredging \& Anor. v. U.T.B. Trustees Ltd. (2010) LPELR - 3864 (CA) 21-22, D-E, where the Court of Appeal held that, although, the FHC can transfer to the State High Court, the State High Court cannot bilaterally transfer to the FHC. See Chevron Nigeria Limited v. Famuye \& Ors. (2011) LPELR - 8777 (CA) 6-7, C-A, where the Court of Appeal held in opposition to the first case that the State High Court can competently transfer suits to the FHC if it found that it had no jurisdiction and that the FHC had. See also the unreported decisions of the Court of Appeal in Suit No. FCA/L/87/83: Uthman \& Ors. v. Katagun \& Co. Ltd ${ }^{2}$; and Suit No. CA/L/36/84: Chima Ocean Shipping Co. Ltd. v. Allied Trading Co. These decisions also held that the High Court cannot transfer to the FHC. It is thus clear that the Court of Appeal, as well as the Supreme Court, and the High Court, are all bedeviled by the recondite question of whether the High Court of a State can transfer cases to the FHC.

${ }^{3}$ Aluminium Manufacturing Co. Ltd. v. N.P.A. (supra); Associated Discount House Ltd. v. Amalgamated Trustees Ltd (supra); and Fasakin Foods (Nig.) Ltd. v. Shosanya (supra) on the one hand; and Omisade v. Akande (supra) on the other.
} 
transfer of cases over which they lack jurisdiction ${ }^{l}$. This decision itself was based on two earlier unreported decisions of the Court of Appeal. The first is, Suit No. FCA/L/87/83: Alhaji Uthman \& Ors. v. Alhaji Sule Katagun $\&$ Co. Ltd ${ }^{2}$ and, the second is, Suit No. CA/L/36/84: Chima Ocean Shipping Co. Ltd. v. Allied Trading Co ${ }^{3}$. The first was decided on $16 / 6 / 83$, while the second was decided on 10/11/84 ${ }^{4}$. The view of the Court of Appeal, though overturned by the Supreme Court subsequently, has however become the proverbial rejected stone that later became the corner stone of the house; as subsequent decisions of the Supreme Court, which held that the High Court of a State cannot transfer cases to the FHC were based on the same reasoning ${ }^{5}$. Though, the subsequent decisions of the Supreme Court in issue did not uphold, in its entirety, the decision, which had totally nullified section 22 of the FHCA, it nevertheless upheld the aspect that, the High Court of a State cannot transfer to the FHC, for precisely the reasons offered by the Court of Appeal in Aluminium Manufacturing Co. Ltd. v. N.P.A . The Supreme Court held that, unless and until a State House of Assembly enacts a law or the High Court Rules of a State is amended to give the High Court of a State the power to transfer suits to the FHC, the High Court of a State cannot exercise the power to transfer, even though, conferred on it by section 22(3) of the FHCA ${ }^{7}$.

The above reasoning is based on the rationale that, being that section 239 of the defunct 1979 Constitution is the section that prescribed the authority vested with powers to make law or practice and procedure for the High Court of a State; and that authority being the House of Assembly of a State, the National Assembly cannot validly make a law or practice and procedure under which the High Court of a State is to transfer cases to the FHC. Such law or practice and procedure, if made, will be ultra-vires the National Assembly. The reasoning itself is an extension of the doctrine of the plenary character of the federating units, as postulated by the eminent professor of constitutional law: Ben Nwabueze, which guaranteed the federating units autonomy within their spheres of influence without interference from the central ${ }^{8}$. This appears to have been the basis of the Supreme Court's decision in A-G Lagos State v. A-G Federation and $\mathrm{Ors}^{9}$ when it held that, a State Government in Nigeria has exclusive power to make planning laws and regulations within its jurisdiction under the Residual List and declared Decree No. 88 of 1992 [later Act] void to the extent of its inconsistency with the 1999 Constitution. This Decree, which later became an Act of the National Assembly, legislates on issues of town planning for the States of the Federation. It held sway during the military era because of the superiority of Decrees over the unsuspended parts of the 1979 Constitution. Attempts by the Federal Government, at the inception of the 1999 Constitution to rely on this Decree against Lagos State Government were resisted and the Decree was invalidated in the ensuing suit.

Flowing from the foregoing, the provisions of section 22 of the FHCA and those of section 24 of the NICA that attempt to confer powers on the High Court of a State to transfer cases over which they lack jurisdiction to the FHC and the NICN therefore, are ordinarily without more, void to the extent of their inconsistency with section 239 of the 1979 Constitution which expressly and directly gave these powers to the House of Assembly of a State, and now sections 273 and 274 of the 1999 Constitution [as altered]. The provisions relating to powers of courts to transfer cases inter se might have held sway during the military interregna when Decrees were superior to the unsuspended parts of the 1979 Constitution, but with the ascendance of the 1999 Constitution, the tide changed. The FHC or the NICN for that matter, cannot even, based on the reasons adduced so far by our courts in the authorities cited, transfer to the High Court of a State, for it has no power to en-burden it, and vice versa. For the avoidance of doubt, section 274 of the 1999 Constitution [as altered] provides:

"Subject to the provision of any law made by the House of Assembly of a State, the Chief Judge of a State may make rules for regulating the practice and procedure of the High Court of the State".

Arising from the foregoing, there appears to be good basis for the decision that the State High Court cannot transfer to the Federal High, and ipso facto, to the NICN, any matter over which it is not seised of jurisdiction and on which either of the two-mentioned courts have jurisdiction. The reasoning is logical and consistent with the doctrine of autonomous existence of the federating units. A peer into the antecedents of this principle in the 1963 Constitution ${ }^{10}$, will justify the fact that, this is the intendment of the constitutional framework embedded in section 239 of the 1979 Constitution and sections 273 \& 274 of the 1999 Constitution [as altered]. Reviewing the 1979 Constitution, Nwabueze has admirably stated the principle to the effect that, it amounts to constitutional infractions for the central government to compel obligations on the part of the States or assign them duties not assigned by

\footnotetext{
134, B-C; 36-37, G-A (supra).

2 36, B-D Aluminium Manufacturing Co. Ltd. v. N.P.A. (supra).

${ }^{3}$ Ibid.

${ }^{4}$ Ibid.

${ }^{5}$ Fasakin's case (supra).

${ }^{6}$ Fasakin's (supra).

${ }^{7}$ Ibid, 38-39, E-G.

${ }^{8}$ Cited in Federal Republic of Nigeria v. Anache (M) \& Ors. LER (2004) SC 316/2001 at 42.

9 (2003) LPELR - 620 (SC).

${ }^{10}$ The Constitution of the Federation, 1963.
} 
the constitution and vice versa ${ }^{1}$. This principle remains sacrosanct with regard to the 1999 Constitution [as altered]. In opposing this posture, the proponents of the pro-powers of inter-courts transfer of cases also rest their arguments on the fact that, section 230(2) of the 1979 Constitution validated the provisions of sections 22(2) \& (3) of the FHCA and by logical implication, section 24(2) \& (3) of the NICA, which purport to give to the High Court of a State, powers of transfer of cases to the two courts and vice versa. With regards to the powers of the High Court of a State to transfer cases to the FHC, the Supreme Court specifically held:

"But there is power in the provision in section 230(2) of the Constitution 1979 which vested in the State High Courts the power of transfer provided in section 22(3) of the Federal High Court Act 1973 as amended by Decree No. 36 of 1975. This section which is an existing law could be relied upon in such situations. This power is vested in the State High Courts by the Constitution and not as the Court of Appeal erroneously thought by virtue of the Federal High Court Act, $1973^{2} . "$

The above aspect of the Supreme Court's decision tallies completely with its earlier decision in Omisade v. Akande [supra], which firmly decided that the High Court of a State has the power to transfer cases to the FHC. Since the basis of the ratio is that section 230(2) of the 1979 Constitution incorporated section 22(3) of the FHCA. It is therefore compulsory to examine this assertion critically. Being a constitutional issue, it is apropos to start by reproducing the provisions of the said section 230(2) of the 1979 Constitution to give it the attention it deserves:

"Notwithstanding subsection (1) of this section where by any law any court established before this section comes into force is empowered to exercise jurisdiction for hearing and determination of any matters to which subsection (1) of this section relates, such court shall as from the date when this section comes into force be restyled "Federal High Court", and shall continue to have all the powers and exercise the jurisdiction conferred upon it by any law".

It must be said, with utmost humility that, it is not easy to fathom how it comes about that this section is being touted as giving the High Court of a State the power to transfer cases over which it lacked jurisdiction to the FHC. A careful perusal reveals that all that the section did was to confer powers on the FHC to exercise all those powers and jurisdiction hitherto exercised by its predecessor: the FRC. It is clear that it does no more. And this cannot by any stretch of imagination be interpreted as conferring equally on the High Court of a State the power to transfer cases to the FHC. "The express mention of one thing', the maxim states, "is the exclusion of the other"." This is because, the power conferred on the High Court of a State by section 22(3) of the FHCA, is not conferred on the FHC, it is conferred on the High Court of a State and, it is for this reason that it is envisaged that the High Court of a State will exercise its power under a Law made by the State's Legislature or a rule of court made for the High Court of the State by the State's legislature ${ }^{4}$. Section 22(3) of the FHCA that confers on the High Court of a State power to transfer is logically not saved by the provisions of section 230(2) of the 1979 Constitution relied upon. Section 230(2) only saves powers to be exercised by the FHC. Section 22(3) of the FHCA, having not conferred power on the FHC, is saved rather by the provisions of section 274 of the defunct 1979 Constitution, which saved all existing laws enacted before the 1979 Constitution came into force. As such, it will be subject to the provisos contained in subsections (1)(a) and (b), and particularly, subsection (3) of the said section 274 of the 1979 Constitution. By these subsections, the defunct 1979 Constitution subjected such laws to the test that, they must be laws validly made by the enacting authority, and that, the courts of the land reserved the powers to invalidate any such law considered repugnant to any other law or the Constitution. It is axiomatic that the enacting authority must priorly have the jurisdiction to make such law. Where it does not, the law will be invalidated.

In this situation, it would appear safe to argue that the provision of section 22(3) of the FHCA which tries to burden the High Court of a State with the responsibility of transferring cases to the FHC, are void and cannot be validated under section 230(2) of the 1979 Constitution, the National Assembly not having the competence to make laws in that behalf by virtue of section 239 of the 1979 Constitution, which gave the House of Assembly of a State exclusive jurisdiction in this respect. Then, the pertinent question is: can the National Assembly, via section 22 of the FHCA, legislate to burden the High Court of a State with a duty or confer it with a power or function it constitutionally lacks? Sections 239 of the 1979 Constitution and 273 - 274 of the 1999 Constitution answer this question in the negative. Based on these provisions simplicity, the High Court of a State will not be under any obligation to accept transfer of any case from the FHC and neither will it be bound to transfer a case to the FHC. The much talked about bilateralism hazarded by the Supreme Court in Aluminium Manufacturing Co. Ltd. v. N.P.A [supra], with the greatest respect, cannot be achieved by compulsion, as postulated. In this respect, the decisions of the courts that the State High Court lacks power to transfer to the FHC, and perhaps the NICN, are based on better foundation, than those that say the High Court of a State has the power to transfer. This is, if based on the reasons given in the decisions. For clearly section 239 of the spent 1979 Constitution says:

\footnotetext{
${ }^{1}$ Nwabueze, B.O., The Presidential Constitution of Nigeria (1982), C. Hurst \& Company, London at 40.

${ }^{2}$ Aluminium Manufacturing Co. Ltd. v. NPA (supra) 44-45, G-B.

${ }^{3}$ Buhari \& Anor. v. Yusuf \& Anor. (2003) LPELR - 812 (SC) 18, C-E.

${ }^{4}$ S.239 of 1979 Constitution.
} 
"The High Court of a State shall exercise jurisdiction vested in it by this Constitution or any law in accordance with the practice and procedure (including the service and execution of all civil and criminal processes of the court) from time to time prescribed by the House of Assembly of the State."

When the provision of a statute, including that of a constitution, is clear and its literal interpretation does not lead to absurdity, it must be so interpreted ${ }^{1}$. The provision says in an unmistakable manner that, it is the State House of Assembly that can make provisions for the practice and procedure to be followed by the High Court of a State in exercising any jurisdiction actually bestowed on it and not otherwise. This, the state does not share with the National Assembly; and for this reason, all superior courts of the land have similar provisions. For Federal courts, this power is ceded to the National Assembly, and for the High Court of the FCT, Abuja, this power, is equally vested in the National Assembly, being a quasi-federal Court. The principle of law is that, the express mention of one thing is the exclusion of the other ${ }^{2}$. The attempt by the National Assembly, without jurisdiction, to prescribe the practice and procedure to be followed by the High Court of a State on transferring cases over which it lacks jurisdiction to the FHC or the NICN or the FCT High Court, is simply ultra vires the National Assembly. The observation of the Supreme Court ${ }^{3}$ succinctly captures the principle that, in a federation, each tier of government must be strictly confined to its legislative and executive spheres of influence:

"In Nigeria in order to underscore the federal nature of the country, the Constitution divides the Legislative Lists between the components of the Federal Structure. ... It is also important to bear in mind that generally the principle of federalism requires that the Central and State Governments shall be independent of one another within its jurisdiction or legislative competence. None is subordinate to the other but coordinate with one each other. It is therefore necessary to understand that each of the federating State governments is not an appendage of the central government but as an autonomous and independent entity being able to exercise its constitutional responsibility the way it sees fit. But it is important to bear in mind always that the constitutional provision overrides the principle of federalism ${ }^{4} . "$

It follows that the validity of all laws must be tested against the Constitution in a Federal State like Nigeria. While treating similar issue of attempt by Decree No. 47 of 1992 [later Act] to confer exclusive jurisdiction on the NICN in contravention of the provisions of sections 6 and 272 of the 1999 Constitution, the Supreme Court, in a very clear language, held that Decree No. 47 of 1992 is void to the extent of its inconsistency with the 1999 Constitution ${ }^{5}$ :

"Again, it is trite law that the jurisdiction of the State High Court as conferred by the Constitution can only be curtailed or abridged or even eroded by the Constitution itself and not by an Act or Law respectively of the National Assembly or State House of Assembly, meaning that where there is conflict in that regard between the provisions of the Constitution and the provisions of any other law of the National Assembly or House of Assembly respectively the constitution [sic] shall prevail if I may emphasize excepting as I have observed above by direct and clear provision in the Constitution itself to that effect ${ }^{6}$."

The further argument that the provisions of section 22(2) \& (3) of the FHCA 1975 was incorporated in the defunct 1979 Constitution by virtue of section 230(2), and as such valid, with due respect, cannot hold. The provisions, apart from the earlier argument that, section 22(3) of the FHCA is not incorporated by section 230(2), as touted, in the second place, not being directly enacted into the spent 1979 Constitution, they cannot enjoy the same sanctity with the direct and clearly stated contrary provisions of section 239 the extinct 1979 Constitution. Similar arguments to justify some draconian provisions of the Land Use Act ${ }^{7}$, which run contrary to some specific provisions of the 1979 Constitution, were not bought and, the said draconian provisions were held invalid ${ }^{8}$ in spite of the supposedly incorporation of the Land Use Act into the 1979 Constitution. Provisions of an Act, even if incorporated into the Constitution, cannot override any other provisions of the Constitution 9 .

So, the provisions of section 22 of the FHCA could not have validly conferred powers of inter-courts' transfers between the FHC and the High Court of States. Besides, a close scrutiny of the said section 230(2) of the 1979 Constitution clearly conferred no more on the FHC than the power to "... exercise jurisdiction for hearing and determination of any cause or matter to which subsection (1) of this section relates..." The jurisdiction thus

\footnotetext{
${ }^{1}$ Dangana \& Anor. v. Usman \& Ors. (2012) LPELR - 7827 (SC) 32-33, G-E; and A.T. Ltd. v. A.D.H. Ltd (2007) LPELR - 454 (SC).

${ }^{2}$ Buhari \& Anor. v. Yusuf \& Anor. (2003) LPELR - 812 (SC) 18, C-E (supra).

${ }^{3}$ In Attorney-General, Abia State v. Attorney-General, Federation [2006] LPELR - 613 (SC).

${ }^{4}$ Ibid, 201-203, G-B.

${ }^{5}$ NUEE \& Anor. v. BPE (2010) LPELR - 1966 (SC).

${ }^{6}$ Ibid, 8-39, F-A.

${ }^{7}$ CAP. L5, LFN, 2004.

${ }^{8}$ Kamada v. Governor of Kaduna State (1986) 4 NWLR (Pt. 35) 361 at 389; Nwocha v. Governor of Anambra State (1984) 6 SC $362 ;$ (1984) LPELR - 2052 (SC).

${ }^{9}$ Ibid.
} 
conferred on it by this subsection is limited to hearing and determination of the items listed in section 230(1) of the defunct 1979 Constitution. Transferring a matter to the High Court of a State, not being a jurisdiction exercised to hear and determine such a transferred case and not being a jurisdiction to hear and determine any of the items listed in section 230(1) of the 1979 Constitution, is logically not incorporated. To "hear and determine", simply means to assume jurisdiction on a case and hear it to conclusion. A case to be transferred inter-courts for lack of jurisdiction is not even heard let alone, being determined. In essence, the whole of section 22 of the FHCA was not saved by section 230(2) of the 1979 Constitution.

The intendment of subsection (2) of section 230 of the 1979 Constitution is brought to light by subsection (1)(a) of the section, which provided that the National Assembly could only give the FHC additional jurisdiction and powers only on items on which it had powers to make laws. It is clear that the National Assembly has no power to make any law that will interfere with the autonomy of a State Judicature and Legislature dictated by sections $6(1)-(3) \&(5)(\mathrm{g}) \&(\mathrm{~h}), 230(1)(\mathrm{b})$ and 239 of the expired 1979 Constitution ${ }^{1}$. Being courts of coordinate jurisdiction, the FHC cannot exercise supervisory or appellate or directive jurisdiction over the High Court of States. These sections show the clear intention that; the FHC and the High Court of a State were independent courts of co-ordinate jurisdiction under the defunct 1979 Constitution. So, the validity of the powers to transfer inter se these courts ought ordinarily to be sought elsewhere in the 1979 Constitution, and not in section 230(2); and where there is none, that should be the end. When section 22 of the FHCA was originally enacted, it was not valid because of any constitutional backing but simply because of the superiority of decrees over the Constitution.

Be that as it may, another dimension has been introduced into the problem by the enactment of the 1999 Constitution [as altered], which in a way has solidly validated the foregoing arguments and deductions. The provision of section 230(2) of 1979 Constitution, upon which the pro-powers to transfer postulation is based, is not repeated in the 1999 Constitution [as altered]. Consequently, the implication is that, all matters relating to the exercise of powers of inter-courts transfer of cases under section 22(2) \& (3) of the FHCA are now entirely to be governed by the FHCA alone. That the Act is now an ordinary Act like all other Acts of the National Assembly, is no longer in doubt. The issue of its being incorporated into the 1979 Constitution is absolutely no longer tenable under the extant 1999 Constitution. The direct implication of this is that, the cases holding as sacrosanct the powers of inter-courts transfer of cases inter se the courts of co-ordinate jurisdiction in Nigeria are now distinguishable on the basis that section 230(2) of the 1979 Constitution on which they were based, is no longer in existence. The effect of this being that, the superior courts are not now bound at all to apply these decisions on the seemingly settled case law that the FHC can validly transfer cases to the High Court of a State ${ }^{2}$, the High Court of a State not being under the legislative competence of the National Assembly, which enacted the FHCA and; and ipso facto, the NICA.

It follows that the validity of section 22 of the FHCA as existing provisions of an Act of the National Assembly is now to be entirely governed by the provisions of section 315 of the 1999 Constitution [as altered]. And in this wise, its provisions shall, like all normal Acts of the National Assembly, be subject to the powers of courts to invalidate any of the provisions of an Act of the National Assembly that run contrary to the 1999 Constitution [as altered], in accordance with the provisions of subsection [3] of the said section 315 of the 1999 Constitution [as altered]. The same thing is applicable to the provisions of the NICA; NICA being from inception an ordinary Act of the National Assembly, not having at any time enjoyed controversial incorporation into the Constitution. In sum total, the provisions of section 22(2) \& (3) and section 24(2) \& (3) of the FHCA and the NICA respectively, are now fully subjected to the invalidating powers of the courts. And as pointed out earlier, the provisions, just exactly as the Court of Appeal held in Aluminium Manufacturing Co. Ltd v. NPA [supra], are not tenable now under the conditions adduced by the decisions reviewed above. We have to await a restatement of the law from our courts, especially the Supreme Court, in the light of the new changes effected by the 1999 Constitution [as altered] in this area of the law.

\subsection{Validity of Inter-Courts Transfer between Federal Courts}

A perfunctory observation might suggest that, since the three Federal Courts of co-ordinate jurisdiction: the FHC, the NICN and the FCT High Court, are within the legislative competence of the National Assembly, the powers of inter-courts transfer of cases between these courts would remain sacrosanct. The caveat however, is that, since federalism prescribed a legalistic government ${ }^{3}$, as such, it does not follow that the powers of the National Assembly to legislate on authorities within its legislative competence are unlimited. These powers are limited to the extent that, it does not make any law, which conflicts with the express provisions of the Constitution or on any matter on which the Constitution has made exhaustive provisions, with the clear intention that, those provisions shall govern the situations envisaged. Even if those items on which such laws are made are within either the Exclusive or Concurrent Legislative Lists, they shall still be declared invalid. The Supreme Court clearly demonstrated the

\footnotetext{
${ }^{1}$ Dairo v. Union Bank of Nigeria Plc \& Anor. (2007) - 913 (SC) 30-31, E-G.

${ }^{2}$ N.U.T., Niger State v. COSST, Niger State (2012) 10 NWLR (Pt. 1307) (CA) 89 114, A.

${ }^{3}$ Attorney-General, Abia State v. Attorney-General, Federation (supra).
} 
truism of this assertion when it held that the National Assembly could not prescribe additional conditions, aside those already prescribed by the 1999 Constitution for an association to be registered as a political party in Nigeria ${ }^{1}$.

Giving the provisions of section 6(3) of the 1999 Constitution [as altered], which says, “... each court shall have all the powers of a superior court of record", each of the courts specified in section 6(5) of the 1999 Constitution [as altered] shall be independent of one another except as otherwise prescribed in the Constitution itself. That is why the phrase "each court" is used as against 'all the courts'. By a construction of the whole provisions of the said section 6(3) of the 1999 Constitution [as altered], the National Assembly or the House of Assembly of a State may limit or extend the power of a superior court of record granted each of the courts under its jurisdiction but cannot extend or limit the jurisdiction of any of them via enactment of an ordinary Act without constitutional alteration. The tenors of sections 252(2) and 254D - (2) of the 1999 Constitution [as altered] are that the National Assembly can only confer additional powers on the FHC and the NICN for the purposes of better exercising the jurisdiction already conferred upon them by the 1999 Constitution [as altered]: no more, no less. The concomitance of this argument is that, the National Assembly cannot, based on the reasons that have been offered in the cases reviewed, confer powers of transfer inter se Federal Courts of co-ordinate jurisdiction in Nigeria, not being powers to better exercise the jurisdiction already conferred on them by the Constitution, but powers to actually exercise jurisdiction not constitutionally conferred. To do this will be tantamount to granting jurisdiction through the backdoor and would be liable to be struck down like the Supreme Court struck down the jurisdiction conferred on the NIC by NICA $2006^{2}$.

\subsection{Rules of Courts and Powers of Inter-Courts Transfer of Cases}

It appears that wherein the Rules of any High Court of a State provides for taking any step that would ensure justice where there is lacuna in its Rules; and there are no positive rules of the court and/law of the State violated, or if the steps allowed by the Rules is accommodative of the Rules of other courts, there is nothing stopping the court lacking rules of transfer to borrow from such courts the power to transfer or, transferring the matter outright, in the interest of justice as permitted by its rules relating to lacuna ${ }^{3}$. A cursory look at section 274 of the 1999 Constitution [as altered], which gives the Chief Judge of a State powers to make rules for regulating the practice and procedure in a State's judicature appears to support this view. But the snag here is that, such rules of court, if relied upon to transfer cases to other independent courts, are contradictory to the plenary character of the judicature of the State concerned ${ }^{4}$. Though, section 274 of the 1999 Constitution [as altered] did not expressly say such rules as made by the Chief Judge of a State must be subject to the Constitution: it only says such rules shall be subject to the laws made by the House of Assembly of a State. By virtue of sections 1(3) and 315(3) of the 1999 Constitution, any rules of court considered diminishing the independence of the federating units and any of their organs is liable to be struck down. Even the State House of Assembly and the National Assembly cannot by consent or otherwise legislate out of the spheres of influence for each as dictated by the 1999 Constitution [as altered]. To legislate on inter-courts transfer of cases is to make a cross-boundary law against the spheres of influences of both. This is the essence of legalistic government, which Federalism presupposes ${ }^{5}$. If such rules as made by the Chief Judge are made subject to the laws of the House of Assembly of a State, they must logically be much more subject to the grundnorm: the 1999 Constitution [as altered].

It is necessary to bring out the clear distinction between the provisions of section 239 of the expired 1979 Constitution and that of section 274 of the 1999 Constitution, which replaced it, before going further in this treatise. This distinction necessitates important consequences. Under section 239 of the extinct 1979 Constitution, the practice and procedure made for the High Court of a State acquired the force of law, since they were enacted by the House of Assembly of a State, whereas under section 274 of the 1999 Constitution [as altered], the powers to make rules for the High Court of a State are ceded directly to the Chief Judge of the State concerned. Such rules of court and their prescribed practice and procedure only acquire the force of a subsidiary legislation/law ${ }^{6}$. The consequence is that, while the powers to confer seemingly additional jurisdiction on the High Court and the powers

\footnotetext{
${ }^{1}$ INEC v. Musa (2003) LPELR - 1515 (SC) 36-37, F-D. See also NUEE \& Anor. v. BPE (supra), where the attempt of Decree No. 47 of 1992 to confer the NIC with exclusive jurisdiction against the spirit of the 1999 Constitution was declared invalid.

${ }^{2}$ N.U.E.E. v. BPE (2010) LPELR-1966 (SC) 42-42, F-D.

3 See Okewale v. Governor of Oyo \& Ors (2018) LPELR-46017 (CA), which, with the utmost respect, went to the extreme of unconstitutionality. The Chief Judge of Oyo State purportedly relied on such rule to administratively transfer a case to the NICN by a letter under His Lordship's hand and not by order of Court; an act clearly unconstitutional, and for that reason, turned down by the NICN, but which, with the greatest respect, the Court of Appeal surprisingly upheld, for the NICN is not under the administrative control of the Chief Judge, Oyo State. See also Order 45, Rule 13, Osun State High Court Amended (Civil Procedure) Rules, 2008, which was relied on to transfer Suit No. HOS/93/2011: Abidemi Hammed \& Ors. v. Osun State Government \& Ors. from the Osun State High Court to the NICN. The ruling transferring the case was delivered on 15/05/2012. See also Order 22, Rule 1, Abia State High Court (Civil Procedure) Rules, 2009; and Order 22, Rule 2 (1) \& (2) and Order 45 (14) of the Akwa Ibom State High Court [Civil Procedure] Rules. Similar rules abound in virtually all the High Court Rules of all the States of the Federation.

${ }^{4}$ Clement \& Anor. V. Iwuanyanwu \& Anor (1989) LPELR - 872 (SC) 38, E-F.

${ }^{5}$ Attorney-General, Abia State v. Attorney-General, Federation (supra).

${ }^{6}$ Owners of the MV “Arabella” v. Nigeria Agricultural Insurance Corporation (2008) LPELR - 2848 (SC) 11, D-G.
} 
to specify the practice and procedure were vested in one authority under section 239 of the defunct 1979 Constitution, these powers are separated and assigned to different authorities under sections 273 and 274 of the 1999 Constitution.

However, before going further, it is also necessary to draw attention to the fact that, the additional jurisdiction, if it be, which the provisions seem to suggest the legislatures can confer on the courts, are not inclusive of extending or limiting the jurisdiction already granted by the Constitutions. The provisions of the Constitutions on jurisdictions of superior courts in Nigeria are meant to be exhaustive ${ }^{1}$. It only means a statute can specify whether a matter shall commence at the High Court of a State at first instance or in its appellate jurisdiction. This is because all matters that fall outside the exclusive jurisdiction of the FHC and the NICN are cognizable under the residual but general jurisdiction granted the High Court of a State ${ }^{2}$; so that, where a statute does not specify which court will have jurisdiction, once the matter does not fall within the confines of the exclusive jurisdiction conferred on the FHC and the NICN, it will be cognizable at the High Court of a State. In essence, it means the jurisdiction of any superior court in Nigeria cannot be curtailed or extended without a constitutional alteration ${ }^{3}$. It means any ordinary Act of the National Assembly that attempts to take away part of the residual jurisdiction of the State High Court without constitutional alteration is void. To this extent, the decision of the Court of Appeal in Chevron v. Famuye $^{4}$ [supra] which holds that the National Assembly has validly conferred these powers is, with respect, wrong; more so, when it did not show any specific provision of the Constitution that makes them valid. It is plainly illegal for the National Assembly to attempt to extend or confer additional jurisdiction on the superior courts against the spirit of the Constitution ${ }^{5}$. The conferment of a power on a subject on which a court lacks jurisdiction is tantamount to conferment of jurisdiction through the backdoor ${ }^{6}$. As the 1999 Constitution is presently, the legislatures can only validly confer powers pursuant to the jurisdiction already conferred on each court. The Court of Appeal, in an earlier case ${ }^{7}$, quite appreciated this and correctly stated the position while construing the powers of the FHC to transfer matters over which it lacks jurisdiction pursuant to section 22(2) of the FHCA:

"It is now trite to say that in the absence of jurisdiction, there is no competence to exercise the judicial powers vested in the courts by section 6(6)(b) of the Constitution. ...the Court just cannot do anything else except to strike out the matter. If the Court were to transfer, it means the Court is saying there is limited jurisdiction or a conditional jurisdiction by which after stating that it lacks jurisdiction, the same court would proceed upon no foundation or base to carry out a judicial function like transferring the suit to another court imbued with the appropriate jurisdiction ${ }^{8}$."

This Court of Appeal's decision abovein was firmly confirmed by the Supreme Court in as recent as 2011 in Obiuweubi v. CBN [supra]:

"Once a court lacks jurisdiction, a party cannot use any statutory provision or common law principle to impose it because absence of jurisdiction is irreparable in law. The matter ends there - while the only procedural duty of the court is to strike it out ${ }^{9}$."

Assuming the State Legislature can confer additional jurisdiction under sections 239 of 1979 Constitution and 273 of the 1999 Constitution; the implication is that, while the State Legislature's practice and procedure assume the force of law and could thereby confer additional power or jurisdiction under section 239 of the 1979 Constitution, the rules of practice and procedure made by the Chief Judge under section 274 of the 1999 Constitution cannot confer any additional power or jurisdiction on the High Court of a State; this legislative competence having been given to the State's Legislature under section 273 of the 1999 Constitution. It is in this sense that the Supreme Court held in Fasakin's case [supra] that, the High Court of a State can only competently transfer cases to the FHC, only and only, if there is a State's law to that effect or pursuant to the Rules of a State's High Court ${ }^{10}$; being that, the rules of the High Court of a State under section 239 of the 1979 Constitution, under which Fasakin's cases was decided, have the effect of a law validly made by the State's legislature as against subsidiary legislation that they are now under section 274 of the 1999 Constitution [as altered]. It follows that the Chief Judge can only now regulate how the High Court of a State is to exercise the jurisdiction and powers conferred on it by either the Constitution or the Law of the State under section 274 of the 1999 Constitution [as altered] and cannot add to or detract from them. Apropos of the foregoing, a rule of court cannot confer a court

\footnotetext{
${ }^{1}$ INEC v. Musa (supra) at 36-37, paras. F-D. See also NUEE \& Anor. v. BPE (supra).

${ }^{2}$ Madu v. Mbakwe \& Ors. (2008) LPELR - 8389 (CA) 8.

${ }^{3}$ NUEE v. BPE (supra) 38-39, F-A. See also Madu v. Mbakwe \& Ors. (supra).

${ }^{4} 6-7, \mathrm{C}-\mathrm{A}$.

${ }^{5}$ Job Ike \& Ors v. PatricK Nzekwe \& Ors. (1975) LPELR - 1468 (SC) 9-10, C-A.

${ }^{6}$ Chevron v. Famuye (supra) 6-7, C-A, shows clearly that conferment of powers of inter-courts transfer of cases on which a court lacks jurisdiction is a conferment of jurisdiction.

${ }^{7}$ Bamak Pharmacy \& Stores Ltd. \& Anor v. Abuja Municipal Area Council (2010) LPELR - 3850 (CA).

${ }^{8}$ Ibid, 33-34, G-E.

${ }^{9}$ Obiuweubi v. $C B N$ (supra) 42, D-G.

${ }^{10}$ Fasakin Foods [Nig.] Ltd v. Shosanya (2006) LPELR - 1244 (SC) 38-39, E-G.
} 
with a substantive power to exercise jurisdiction, which it lacks statutorily ${ }^{1}$. For power is an offshoot of jurisdiction. Power of inter-courts transfer of cases is a radical and substantive power, which can only be conferred on a court by the statute under which the jurisdiction of the court is granted. This is because a court assumes all its powers from its jurisdiction to adjudicate a case. Where a court lacks jurisdiction, it cannot exercise any power. The Supreme Court ${ }^{2}$ has unequivocally laid this to rest:

"Where a court has no jurisdiction with respect to a matter before it, the juridical basis for the exercise of any power with respect to such matter is also absent. This is because power can only be exercised where the court has jurisdiction to do $\mathrm{so}^{3}$."

For a rule of court to attempt to grant power to a court over a matter on which it lacks jurisdiction is logically tantamount to attempting to confer the court with a jurisdiction it lacks under the statute creating it. It is submitted that, this, no rule of court can do. Since rules of court do not confer jurisdiction on courts in Nigeria ${ }^{4}$, it follows that they cannot confer any power ${ }^{5}$ of inter-courts transfer of cases, which is a derivative of jurisdiction when such a court lacks jurisdiction ab initio. It is the 1999 Constitution [as altered] that confers jurisdiction on superior courts in Nigeria ${ }^{6}$. It follows that rules of court only avail a court when it has jurisdiction on the matter in question. Rules of court are made strictly to guide the courts on how to exercise their jurisdiction: no more, no less. Where a court lacks jurisdiction, it cannot rely on its rules to do anything, exercise any power or give any order since the exercise of power is a function of prior jurisdiction over a case $\mathrm{e}^{7}$. Therefore, rules of courts follow the jurisdiction of courts and not vice versa. The 1999 Constitution [as altered] does not envisage that the Head of any Court in Nigeria will have the power, through enactment of rules of court, to confer additional jurisdiction on a court, which the 1999 Constitution itself did not confer on the court or to give to a court the right to exercise any power not in furtherance of the jurisdiction already conferred by the 1999 Constitution.

It should be noted that the inherent powers of court preserved by section 6(6)(a) of the 1999 Constitution [as altered] as regards matters over which a court lacks jurisdiction is the power to strike out such matter ${ }^{8}$. Section 6(3) of the 1999 Constitution [as altered] becomes relevant here:

"The Courts to which this section relates, established by this Constitution for the Federation and for the States, specified in subsection (5)(a) to (i) of this section, shall be the only superior courts of record in Nigeria; and save as otherwise prescribed by the National Assembly or by the House of Assembly of a State, each court shall have all the powers of a superior court of record" [Italics for emphasis]

By the above provisions, it is clear that the courts to which the section relates shall individually have all the powers of a superior court of record. By employing the phrase "... all the powers..." with the definite article "the", it presupposes that these powers are definite and are generally known or are to be easily located. It is also clear that the powers referred to under section 6(3) of the 1999 Constitution [as altered] are wider than those in section 6(6)(a). The implication is that, both strictly statutory and inherent powers are captured under section 6(3), while only inherent powers are captured under section 6(6)(a). It is also clear that the relevant legislature may add to or subtract from the strictly statutory powers but cannot detract from the inherent powers: that is, section 6(6)(a), which comes later in sequence, is superior to section 6 (3), which comes earlier and, detracts from it. This is the distinction between section 6(3) and 6 (6)(a) of the 1999 Constitution [as altered], otherwise, there would not have been any need for section 6(6)(a). The Court of Appeal clearly underscored this distinction':

"An inherent power has to be inherent in the sense that it forms an essential and intrinsic element in the whole process of adjudication. It is innate in a court, and is not a subject of specific grant by the Constitution or by legislation. That is why inherent powers of courts cannot be taken away or abridged by legislation for he who gave, he only can take away. This explains section 6(6)(a) of the 1979 Constitution which merely recognized and stated the obvious - that the inherent powers of a court of law exist 'notwithstanding anything to the contrary in this Constitution'. As soon as any court is established, all its inherent powers adhere and attach to it $^{10}$." [Italics for emphasis]

However, some decisions of the appellate courts seem to suggest that inherent powers of courts in Nigeria

\footnotetext{
Afribank Nigeria PLC. v. Akwara (2006) LPELR - 199 (SC) 41, A-C.

${ }^{2}$ Ajomale v. Yaduat \& Anor. (Ruling) (1991) LPELR - 305 (SC) 8, E-G.

${ }^{3}$ Ibid. See also Obiuweubi v. CBN (supra).

${ }^{4}$ Onuorah v. Kaduna Refining \& Petrochemical Co. Ltd. (2005) LPELR - 2707 (SC) 10, D-E.

${ }^{5}$ Afribank Nigeria PLC. v. Akwara (supra).

${ }^{6}$ Ibid, at. 7, paras. A-C. See also Osadebay v. A.G. Bendel State (1991) 1 NWLR (Pt. 169) SC 525 at 532, ratio 1.

${ }^{7}$ Gombe v. P.W. (Nigeria) Ltd. \& Ors. (1995) LPELR - 1330 (SC) 27-28, F-C.

${ }^{8}$ Williams (Junior) v. Williams (1995) LPELR-3483 (SC), 18, C-E; Garba v. Mutallab (2015) LPELR-40742 (CA) 25-26, F-E; and Gombe v. P.W. [Nig.] Ltd. \& Ors. op. cit. $29-30, \mathrm{~B}-\mathrm{A}$.

${ }^{9}$ Ogwuegbu v. Agomuo \& Ors. (1999) LPELR - 6686 (CA).

${ }^{10}$ Ibid, 49-51, E-A.
} 
are vague or nebulous ${ }^{1}$ and as such, are not capable of being known in advance; and that, as they are not conferred by statutes, they are inferior to any statutory power, including rules of court ${ }^{2}$. In short, it appears that the distinction drawn above is not appreciated. In order to make informed comments on the above observations, it is necessary to reproduce the provisions of section 6(6)(a) of the 1999 Constitution that conferred inherent powers on our courts:

"The judicial powers vested in accordance with the foregoing provisions of this section -

Shall extend, notwithstanding anything to the contrary in this Constitution, to all inherent powers and sanctions of a court of law..."

The phrase "foregoing provisions of this section" clearly refers to section 6(3) of the 1999 Constitution [as altered], which is the only section preceding section 6(6)(a) of the 1999 Constitution [as altered] that conferred powers on the courts created by section 6(5) of the 1999 Constitution [as altered]. Similar provisions exist in exactly the same section of the expired 1979 Constitution. It is also clear that the National Assembly and a State's Legislature can add to or detract from the statutory powers of superior courts of record in Nigeria, and ipso facto, inferior courts. Thus, the statutory power of a court to punish for murder is limited to the provision of the statute under which murder is charged. This provision could from time to time be competently reviewed by the appropriate legislature. This is evidently the purport of the italicized portion of section 6(3) of the 1999 Constitution [as altered] earlier quoted. But it is abundantly clear by a construction of the 6(6)(a) of the 1999 Constitution [as altered] that, it is totally forbidden for either the National Assembly or a State's Legislature to detract from or add to the inherent powers as conferred by the 1999 Constitution [as altered]. The Supreme Court has explicitly expounded the implication of the term "notwithstanding" employed in the subsection":

"When the term 'notwithstanding' is used in a section of a statute, it is meant to exclude an impinging or impeding effect of any other provision of the statute or other subordinate legislation so that the said section may fulfill itself ${ }^{4}$."

The implication of the portion of section 6(6)(a) beginning with the word "notwithstanding" is to give preeminence to the provision of the subsection over all other provisions of the Constitution: that is, to secure it against violation. Contrary to the assertion that, inherent powers of courts are not knowable in advance and that they are nebulous, the Supreme Court's decision in Williams (Junior) v. Williams ${ }^{5}$ has put a lie to this, when the Supreme Court clearly asserted that, "Where, therefore, it is obvious...that no further proceedings would help a case, there is inherent jurisdiction in the Court to dismiss or strike out the claim... ${ }^{6}$." This same mantra has been repeated in Garba v. Mutallab ${ }^{7}$, where the Court of Appeal better opined:

"The power of the courts to determine foundational and jurisdictional issues in limine is very well known to law and practice. It is regularly employed by the Courts to check and eliminate vexation or abuse of Court process in all their ramifications. This is part of the inherent jurisdiction of all superior Courts of record. ${ }^{8}$ " [Italics for emphasis]

It is in the same manner, as above, that all the inherent powers of the superior courts are known beforehand. That is the purport of the clear provisions of section 6(6)(a) of the 1999 Constitution. A thing not clearly known in advance or that is nebulous, cannot be preserved. The preservation of inherent powers of our courts by the 1999 Constitution clearly suggests that, these inherent powers are clearly known beforehand and can be located or found somewhere. This is why our courts know when and how to use them. Thus, the inherent powers of the superior courts in Nigeria are absolute and cannot be derogated from by any statute, be it the 1999 Constitution itself, as presently constituted, until an amendment is secured to alter section 6(6)(a). This is the clear intendment and language of section 6(6)(a) of the 1999 Constitution. To argue otherwise is to suggest that there is no difference between the provisions of section 6(3) and section 6(6)(a) of the 1999 Constitution [as altered], or to suggest that, the framers of the 1999 Constitution did not know what they were doing when they inserted the provisions of section 6(6)(a). The Court of Appeal has clearly expounded in its decision that the provisions of section 6(6)(a) are meant for a distinctive purpose of strongly fortifying the inherent powers of the superior courts in Nigeria against violation ${ }^{9}$.

The salient fact borne out by section 6(6)(a) of the 1999 Constitution [as altered] is that 'inherent powers' of courts in Nigeria are also statutory contrary to the Court of Appeal's decision, which says they are not. The inherent powers, which superior courts ordinarily exercise in Nigeria, are traceable to the inherent powers exercised by the superior courts under Common Law in England ${ }^{10}$. One of such powers is undoubtedly the inherent

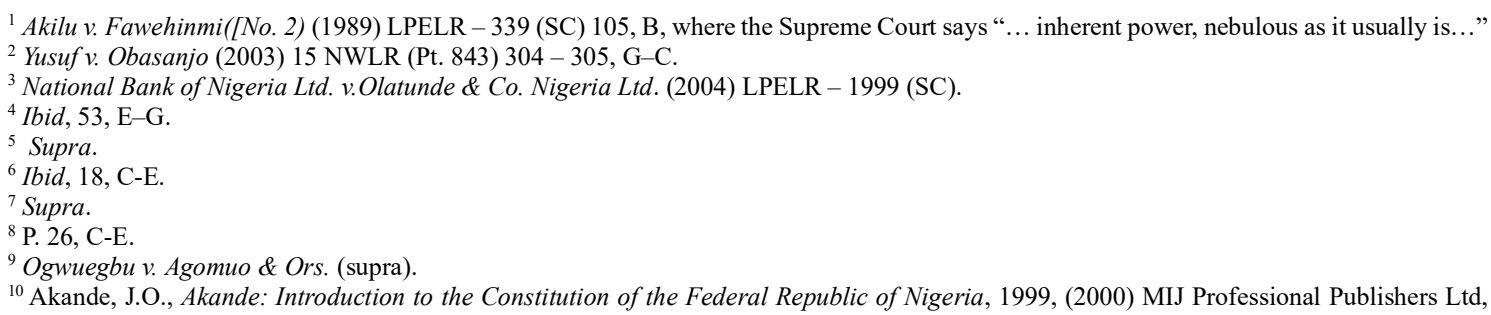


power to strike out cases over which a superior court lacks jurisdiction ${ }^{1}$. A Common Law court never had the power to transfer cases over which it lacked jurisdiction ${ }^{2}$. And in this context, it is necessary to stress that Common Law in Nigeria, is also statutory, by virtue of the various High Court Laws of States in Nigeria, which make Common Law and Equity applicable in Nigeria. It is a true proposition of law that 'inherent powers' follow jurisdiction of court. But by virtue of the absolute guarantee of the 'inherent powers' of Nigerian courts, it follows that, no statute [inclusive of the 1999 Constitution itself, as, it presently, is] or rules of court, can, under the guise of conferment of jurisdiction or powers on a court, erode the inherent powers which are meant to assist the courts in making their jurisdiction effective. The inherent powers exist outside of and are extrinsic to the jurisdiction of courts in Nigeria $^{3}$, which is why they are separately, granted by the Constitution, aside the sections conferring jurisdiction on the courts.

Hence, where there is jurisdiction in a superior court, its inherent powers spring up without any restriction. This view tallies with that of the Supreme Court of England in Fairclough Homes Ltd v. Summers [supra] where it held that, in spite of the codification of powers which superior courts can exercise in England under the CPR Code, inherent powers under Common Law can still be exercised even against the spirit of the CPR Code ${ }^{4}$. That is the purport of section 6(6)(a) of the 1999 Constitution [as altered]. It simply means, even the jurisdictional sections of superior courts in the 1999 Constitution cannot limit the extent of the inherent powers conferred, much less, ordinary statutes. Thus, no statute can legislate against any of the inherent powers of the superior courts in Nigeria. Thus, powers of inter-courts transfer of cases conferred on the courts of co-ordinate jurisdiction in Nigeria are a negation of the absolute guarantee of the inherent powers of superior courts to strike out cases for want of jurisdiction. To show the superiority of inherent powers to rules of court, the judicature in Nigeria has consistently held that, a matter could only be struck out for lack of jurisdiction and not dismissed, even against clear and direct provisions to the contrary in the rules of some courts ${ }^{5}$. It has also been consistently held that preliminary objections touching on jurisdiction could be brought and heard against the rules of court ${ }^{6}$. That the same courts now turn around to say that rules of courts are superior to inherent powers; and that, inherent powers must bow in case of inconsistency ${ }^{7}$, clearly amounts to blowing hot and cold on the same issue.

Related to the foregoing is also that, with the greatest respect, the Court of Appeal is equally wrong in holding that inherent powers of our courts are vague and nebulous ${ }^{8}$. While it might be that the specific instances where a court may exercise inherent powers are not listed or codified, it definitely will be doing violence to the provisions of section 6(6)(a) of the 1999 Constitution [as altered] that these inherent powers are not known. Otherwise, the 1999 Constitution would not have attempted to preserve what is unknown. You can only preserve what is known to exist. Definitely, all the inherent powers exercisable by superior courts of record in Nigeria are known and located within the Common Law. The categories of situations under which these powers can be exercised are also well known. It is only the facts and circumstances of individual cases that might crop up in future that may differ and are not capable of being known in advance; but the context would be constant. And this is true of all Common Law legal principles on which precedents are based.

It follows that inherent powers, if they are nebulous, as claimed, are not any more nebulous than any other common law principle. It is therefore right to say a superior court in Nigeria cannot exercise any inherent power of which it cannot refer to a precedent in the Common Law. It is in this sense that the 1999 Constitution attempts to preserve the inherent powers of courts in Nigeria. That they are not precisely spelt out in statutes is not because they are not capable of being known but because of their great varieties which will make it unwieldy to attempt to do so. This is equally true of all other common law principles applicable in Nigeria, which are not codified. The source, from which they can be found, is known. That inherent powers and their source are known afford our courts guidance in applying them in any given situation. Never has a Nigerian court exercised any inherent power without reference to live examples of where and how such had been applied under Common Law in the past.

Lagos at. 33, where the inherent powers of the superior courts in Nigeria to punish for contempt are traced to England. See also Fasakin 's case (supra), where Niki Tobi JSC traced the inherent powers to strike out cases to the common law - p. 30, A-B

${ }^{1}$ Fasakin's case (supra). 30, para. A. See also Arjay Ltd. \& Ors. v. Management Support Ltd. (2000) LPELR - 6787 (CA) 10-11, F-A; Arubo v. Aiveleru \& Ors. (1993) LPELR - 566 (SC) 18, B-D; Fairclough Homes Ltd v. Summers (2012) LPELR - 17914 (UKSC) 28-29, E-B; Peak Merchant Bank Ltd. v. Venture Trust Company Ltd. (2006) LPELR - 7716 (CA) 13, B-G; and Ofioguma \& Anor. v. Ibuje \& Anor. (2012) LPELR - 7920 (CA) 9-10, F-B.

${ }^{2}$ Fasakin's case (supra) at $14, \mathrm{D}$.

${ }^{3}$ Ogwuegbu v. Agomuo \& Ors. (supra). See also Fairclough Homes Ltd v. Summers (supra) 29, A-B. The Supreme Court of England clearly suggests that the inherent powers of superior courts in England are extrinsic and superior to Rules of Courts.

${ }^{4}$ Fairclough Homes Ltd. v. Summers (supra) 28-29, F-C.

${ }^{5}$ Road Transport Employers Association of Nigeria v. the NURTW (1992) LPELR - 3200 (SC) 15, B-G.

${ }^{6}$ Galadima v. Tambai \& Ors. (2000) LPELR - 1302 (SC) at 21, paras. E-G. See also Nuhu v. Ogele (2003) LPELR - 2077 (SC) 31-32, F-C. ${ }^{7}$ Anambra State Government \& Ors v. Madukwe \& Ors (2011) LPELR-3771 (CA) 25, C where it was stated that “...inherent jurisdiction vested in a Court...cannot be relied on to do the contrary of what a statute makes provision for or what the rules of Court in clear terms provide for." Though, the Court obviously had no jurisdiction in the matter involved, but the statement quoted is a misapprehension of the absolute and exclusive ambit of inherent powers of the superior courts in Nigeria.

${ }^{8}$ Akilu v. Fawehinmi([No. 2) (1989) LPELR -339 (SC) at 105, C. 
Applications of inherent powers by superior courts in Nigeria have always been based on precedents. The courts never exercised one without citing a precedent. So, inherent powers are not nebulous or unknown as claimed ${ }^{1}$.

What the 1999 Constitution attempts to prevent, for example, is that, the Legislatures should, under the guise of conferment of additional jurisdiction or power, take away either the power of court to punish for contempt or to strike out a case for want of jurisdiction. The effect of the phrase, "notwithstanding anything to the contrary" in a statute has been judicially laid to rest beyond resuscitation of further arguments on it ${ }^{2}$. It simply subjects all other provisions of the 1999 Constitution to that sub-section so that, it could fulfill itself without hindrance ${ }^{3}$. As it is now, the inherent powers of our superior courts in Nigeria must be fulfilled without hindrance. The Supreme Court ${ }^{4}$ must have had this in mind when it held that section 6(6)(a) grants unrestricted inherent powers to it:

"The Supreme Court is conferred with unlimited inherent powers by virtue of section 6(6)(a) of the 1999 Constitution as a court of record to jealously guard the judicial process from being ridiculed or scandalized and for the purpose of achieving a just, equitable and expeditious dispensation of justice ${ }^{5}$."

The above view has also been earlier held when the Court of Appeal ${ }^{6}$ said of the entire provisions of section 6(6) of the 1999 Constitution:

"An enactment will infringe the Constitutional provisions of section 6(6) if it has: - (a) Provided [sic] for sharing the judicial powers with any other body other than the courts in which it is [sic] vested by the Constitution. (b) Purported to remove judicial powers vested in the court or redefine it in a manner as to whittle it or (c) Limit the extent of the power vested or conferred on the court ${ }^{7}$."

Since the superior courts in England never had inherent power to transfer cases over which they lacked jurisdiction, it follows that Nigerian courts cannot acquire that power against the absolute preservation of its inherent powers by the 1999 Constitution [as altered] because, the inherent powers of Nigerian courts are traceable to Common Law; the inherent powers of Nigerian Courts preserved, being those of the superior courts of England under Common Law as at $1^{\text {st }}$ January, 1900. Under Common Law, where a court lacks jurisdiction over a case, it cannot exercise any power over the case, excepting the inherent power it has under Common Law to strike out the matter. The highest Court of the land has judicially laid to rest the fact that a court cannot exercise any inherent power where it lacks jurisdiction ${ }^{8}$ :

"In this regard, it ought to be stressed that to equate the jurisdiction vested in a court with the exercise of its inherent powers in a cause within its jurisdiction is a clear misconception The exercise of jurisdiction in a cause or matter must be distinguished from the exercise of an inherent power by a court of law in a cause or matter within its jurisdiction. The inherent power of a court of record is entirely supplementary to and dependent on the statutory jurisdiction of the court in a cause. A court may have or exercise inherent power or inherent jurisdiction in respect of a cause or matter within its jurisdiction. It has, however, no inherent power or jurisdiction over a cause or matter not within its jurisdiction. There lies the distinction between the two terminologies... No inherent power can add to the jurisdiction of any court of record where no jurisdiction to entertain a cause had been vested in the Constitution or Statute law. Inherent power is only exercised to enhance statutory jurisdiction in a cause or matter within the jurisdiction of the Court ${ }^{9}$."

It thus becomes very clear that, rules of court cannot by any stretch of imagination confer powers of intercourts transfer of cases on courts in Nigeria. It should be noted that powers of transfer of cases inter se courts, as they exist now, are granted by statutes ${ }^{10}$, and not by rules of court. It should equally be noted, that, the powers are not in any way related to the practice and procedure of courts derived from the rules of courts, which are meant only to assist the courts in exercising the jurisdiction conferred on them by the Constitution but rather, they are radical powers tantamount to exercising jurisdiction, where there are actual lack of jurisdiction ${ }^{11}$. The rules of a particular court are binding on that court alone or within its sphere of influence, that is, its divisions and the parties to suits filed in the particular court. They do not have extra-boundary effect and neither can they compel obedience

\footnotetext{
${ }^{1}$ Akilu v. Fawehinmi [No2] (supra).

${ }^{2}$ National Bank of Nigeria v. Olatunde \& Co. Nigeria Ltd (supra).

${ }^{3}$ Ogwuegbu v. Agomou \& Ors. (supra).

${ }^{4}$ Dingyadi \& Anor. v. INEC \& Ors. (2011) LPELR - 950 (SC).

${ }^{5}$ Ibid, 40, A-C.

${ }^{6}$ Eje \& Ors. v. Hon. Min. FCT \& Anor. (2007) LPELR - 3574 (CA)

${ }^{7}$ Ibid, 22, B-E

${ }^{8}$ Gombe v. P.W. (Nig.) Ltd. \& Ors. (supra).

${ }^{9}$ Ibid, 27-28, F-C. See also Crownstar \& Company Ltd. v. the Vessel MV Valli P. \& Ors. (1999) LPELR - 6595 (CA) 43, A-B.

${ }^{10}$ The FHCA and the NICA.

${ }^{11}$ Chevron v. Famuye, (supra) at 6-7, C-A.
} 
from another independent court ${ }^{1}$. Courts of co-ordinate jurisdiction in Nigeria are constitutionally all independent of one another ${ }^{2}$. If one makes rules on inter-courts transfer of cases, the rules cannot therefore compel obedience of acceptance of such transferred cases from the other ${ }^{3}$; the courts not having supervisory jurisdiction on one another, so, no rule of court can enable one court of co-ordinate jurisdiction to transfer cases to another ${ }^{4}$. This legal assertion is given judicial imprimatur by the Supreme Court ${ }^{5}$ :

"Section 6 of the said Constitution provides: "(2) The judicial powers of a State Shall be vested in the courts to which this section relates being courts established, subject as provided by this Constitution, for a State." Section 234(1) of the same Constitution established a High Court for each State of the Federation with its Chief Judge and other Judges (section 270 of the 1999 Constitution). Each of the Courts has its own rules of practice and procedure which operate independent of one another ${ }^{6} . "$

Going through the various authorities cited on inherent powers of courts in Nigeria, it is clear that, there is conflict as to whether inherent powers are statutory, ascertainable in advance or not. The argument that inherent powers are contained [expressly stated] in the rules of court and other statutes ${ }^{7}$ is, with respect, misconceived $^{8}$. Yes, inherent powers of superior courts in Nigeria are statutory to the extent that they are conferred and preserved by section 6(6)(a) of the 1999 Constitution, a statute, and contained in the Common Law, which is received into Nigeria also by statutes. That is all: all the inherent powers of the superior courts are to be found in Common Law and not specifically in any statute, code or rules of court. The apparent divergence of opinions stems from five factors: (1) not appreciating the distinction between subsections 6(3) and 6(a) of section 6 of the 1999 Constitution [as altered]; (2) not appreciating that Common Law is equally statutory in Nigeria; (3) not appreciating that all inherent powers of superior courts in Nigeria are derived from the Common Law; (4) not appreciating the distinction between 'jurisdiction' and 'inherent power'; and (5), the confusion arising from the common interchangeable usages of the terms 'inherent power' and 'jurisdiction'. Inherent powers exist as inherent powers simplicity, and not as inherent jurisdiction. A court does have inherent jurisdiction but inherent powers. It is therefore a misnomer to refer to 'inherent power' as 'inherent jurisdiction'.

Legal minds are not expected to use legal terms loosely. The powers specifically set out in statutes like rules of courts and the various statutes prescribing the sanctions which courts can impose for criminal offences [codified] are the statutory powers, which are preserved under section 6(3) of the 1999 Constitution [as altered]. They are the ones that could be altered by ordinary legislations. For example, the powers of courts to impose death sentences for murder and armed robbery are specifically set out in statutes ${ }^{9}$. And they must not conflict with inherent powers specifically and absolutely preserved by section 6(6)(a) of the 1999 Constitution [as altered]. That inherent powers are different from jurisdiction seemed to be underscored by the fact that inherent powers inured in courts irrespective of whether or not it has jurisdiction over a matter, that is, they are latent in courts, but can only be activated by the assumption of jurisdiction, whereas, a court's jurisdiction is not inherent or latent, but must be specifically donated by statute ${ }^{10}$.

Thus, if any statute legislates on issues already covered by inherent powers, such provision of the statute becomes a mere duplication that is inoperative by the doctrine of covering the field ${ }^{11}$ and; if against any specie of inherent powers, it is void $a b$ initio $^{12}$. The principles of inherent powers are to be decoded from a labyrinth of cases. That is the only sense in which inherent powers are not set out in any statute; and in which, it is said that they cannot be legislated upon. Herein emanates the discrepancy from the two different schools of thought; an examination of which suggests that the two schools only individually appreciated a part of the different sides of the anecdotal elephant. As it is now, there are two different sets of statutory powers of courts in Nigeria: the codified and the non-codified. The Supreme Court ${ }^{13}$ obliquely underscored this and escaped the confusion when it held:

"Power that is conferred on a court by statute or by Rules of Court cannot be called inherent power. When therefore that power is taken away, it ceases to be power that can be exercised and

\footnotetext{
${ }^{1}$ Dairo v. Union Bank of Nigeria Plc \& Anor. (2007) - 913 (SC) 30-31, E-G.

${ }^{2}$ Ibid.

${ }^{3}$ Ibid.

${ }^{4}$ Ibid.

${ }^{5}$ Ibid.

${ }^{6}$ Ibid. See also Fasakin's case (supra) 26-27, G-C.

${ }^{7}$ Obioha v. Ibero (supra).

${ }^{8}$ Ogwuebgu v. Agomuo (supra).

${ }^{9}$ Ss. 316 \& 319 of the Criminal Code Act, Cap. C38, LFN, 2004 and s. 2 (b) the Robbery and Firearms (Special Provisions) Act, 1984 , Cap. R11, LFN, 2004 respectively.

${ }^{10}$ Obiuweubi v. CBN (supra) 41-42, E-A. See also Oloba v. Akereja (1988) LPELR - 2583 (SC) 32, B-C.

${ }^{11}$ INEC v. Musa (2003) LPELR - 1515 (SC) 108, C-F.

${ }^{12}$ S. 1 (3) of the 1999 Constitution [as altered]. See also Attorney-General of Abia State v. Attorney-General of the Federation (2006) LPELR - 613 (SC) 201, D-G.

${ }^{13}$ Khalil \& Dibbo Transport Ltd. v. S.T. Odumade \& Ors. (2000) 7 S.C. (Pt. 1) at 69.
} 
so there can be nothing inherent about it to make it exercisable... It would therefore appear that if the High Court of England no longer has jurisdiction to order non-suit, the High Court, Lagos cannot exercise that power under its general jurisdiction. I think the power to non-suit would appear to be power specifically conferred on a court ${ }^{1}$."

Note that the phrase "general jurisdiction" underlined above, as employed by the Supreme Court herein can only refer to 'inherent powers'. It will appear that the basic reason why the Supreme Court held that the High Court of Lagos could not exercise the power of non-suit is because, as at 1883 , which fell within the $1^{\text {st }}$ January 1900 cut-off date of the Statute of General Application, the High Court of England had ceased to have that inherent power. The implication being that, the Common Law received into Nigeria did not include inherent power to nonsuit. So, the Court of Nigeria could not draw from such source to exercise a non-existent inherent power. If the power to non-suit must now exist in Nigeria, it must be specifically donated by statute. The Supreme Court also clearly underscored the salient fact that, all the inherent powers of our courts are to be located squarely within the four walls of Common Law, and that; Nigerian courts have inherent powers to strike out cases. It is in this sense that they are said not to be contained in statutes and not to be capable of being legislated upon. It is also worthy of note to draw attention to the fact that, inherent powers of superior courts in Nigeria, since the coming into effect of section 6(6)(a) of the 1979 and 1999 Constitutions, cannot be compared to those enjoyed in Britain under Common Law. Under Common Law, any statute, including rules of courts, might $^{2}$ be able to curtail inherent powers, but they cannot be so curtailed in Nigeria by virtue of their absolute constitutional preservation.

Bearing in mind the discussion so far, it becomes unassailable that, it is only a clear amendment of the 1999 Constitution, which whittles down the effect of section 6(6)(a) of the 1999 Constitution and makes provisions for the exercise of powers of inter-courts transfer of cases or a statute made pursuant to such a clear alteration of section 6(6)(a) of the 1999 Constitution that can competently confer powers of inter-courts transfer of cases on courts in Nigeria. During Military interregna, when Decrees were superior to the unsuspended parts of the Constitutions then, powers of inter-courts transfer of cases were understandably valid, but with the ascendancies of the defunct 1979 Constitution and the extant 1999 Constitution, the tide changed ${ }^{3}$.

So far, it is clear that, all the attempts made to justify the powers of inter-courts transfer of cases under civilian regimes by our courts have been discredited. It is also abundantly clear that, why the nation's judicature fell into the error of justifying the sanctity of inter-courts transfer of cases under democratic dispensations, is the fact that; that, foremost, it did pay heed to the superiority of decrees during military interregna and that of the constitution under democracy, too, it never took cognizance of absolutism of the inherent powers granted to Nigerian courts by section 6(6)(a) of the 1999 Constitution and the extraterritorial nature of the powers of inter-courts transfer of cases as distinct from intra-court transfer of cases, which is intra-boundary. It is therefore submitted that, the powers of inter-courts transfer of cases as conferred on courts of co-ordinate jurisdiction in Nigeria by sections $22(2) \&(3)$ and 24(2) \& (3) of the FHCA and the NICA respectively are not valid under all our constitutional arrangements: 1963, 1979 and the extant 1999 Constitution.

\subsection{Comparison with the Practice in the United States of America}

Meanwhile, the research shall first examine the method adopted in the United States, which the Nigerian presidential Constitutions ${ }^{4}$ are modeled after and which also inherited Common Law as Nigeria, before attempting to proffer solutions. This is necessary in that, it will illuminate the subsequent discussions on the solutions to this problem. Ordinarily in the U.S., a Federal Court cannot transfer cases to the State Courts and vice versa. The Federal District Court, which has Divisions in each of the States of the U.S. can however transfer cases wrongly filed in one State's Division of its Court to that of another State's Division ${ }^{5}$. This power, as can be seen, is not a power of inter-courts transfer of cases, but rather, that of intra-court transfer of cases within different divisions of the same Court; so, issues of extraterritorial disputes cannot arise. This, the FHC and the NICN, or any court at that, can also do in Nigeria and have been doing, as a matter of unfettered discretion of the heads of the courts. One State's Court in the U.S. cannot transfer to another's court, cases over which another State's Court has jurisdiction but wrongly filed in it ${ }^{6}$. It has to strike out the matter just like in Nigeria ${ }^{7}$.

However, where constitutional issues relating to infraction of due process in capital offences are involved, the U.S. Supreme Court can order transfer to itself, cases, on which it might have ordinarily lacked jurisdiction

\footnotetext{
${ }^{1}$ Ibid, 74-75, 10-5; also reported as Tinubu v. Khalil \& Dibbo Transport Ltd (2000) LPELR-3249 (SC) 10-11, F-C.

${ }^{2}$ Fairclough Homes Ltd. v. Summers (supra) held that, in spite of the codification, the superior courts in England could still exercise inherent powers even against the codified powers.

${ }^{3}$ See $N U E E$ v. BPE (supra) 33, C-D.

${ }^{4}$ The 1979 and 1999 Constitutions.

${ }^{5}$ Farley, A., "How to Transfer Court Cases From One State to Another", at http://www.ehow.com/how 8469875 transfer-cases-o [Site visited on May 7,2013]

${ }^{6}$ Ibid.

${ }^{7}$ Ibid.
} 
[for not coming by way of appeal] by virtue of the Fourteenth Amendment $1868^{1}$. Also cases may be transferred from the court of a State to the Federal District Court in the U.S. in some itemized situations by virtue of Statute 28 U.S.C ${ }^{2}$. The Congress' powers in this regard were:

"...discerned in the Necessary and Proper Clause authorization to Congress to pass laws to carry into execution the powers vested in any other department or officer, here the judiciary ${ }^{3}$."

It is important to reproduce the necessary and proper clause of the US Constitution in issue. It is the last clause of section 8 of Article 1 of the US Constitution, and it provides that:

"The Congress shall have power... to make all Laws which shall be necessary and proper for carrying into Execution the foregoing Powers, or all other Powers vested by this Constitution in the Government of United State, or any Department or Officer thereof." [Underline for emphasis]

Pursuant to these constitutional powers, series of removal and remand jurisdiction were granted the federal courts. Like in Nigeria, the statutory powers of removal and remand were also fiercely attacked in the US in spite of the constitutional enabling provision, which made Ira S. Flory Jr. ${ }^{4}$ to observe:

"The statutes of removal have had attacks made upon them, but the grant of constitutional authority to Congress to pass acts in regard to federal jurisdiction is so wide that the federal courts have uniformly upheld such legislation, even though some of the provisions objected to have been changed by Congress itself. In the state courts there were early cases which denied the validity of the removal statutes, but ever since the United States Supreme Court settled the question by upholding their constitutionality the state courts have submitted to that controlling decision ${ }^{5}$."

Pursuant to these powers the U.S. Congress, in that behalf, enacted the Judiciary Act 1789 dealing with diversity jurisdiction. By virtue of this Act, powers of inter-courts transfer of diversity cases were conferred on the U.S. Federal District Courts. It is equally clear that, where a case is wrongly removed pursuant to the diversity jurisdiction: that is, transferred to the Federal District Court, it can be remanded: that is, transferred back to the State Court ${ }^{6}$. Statute 28 U.S.C. provides for a variety of diversity situations under which both Federal and State Courts can transfer cases inter se in the U.S. Apart from these instances ably provided for by the U.S. Constitution and statutes made pursuant thereto these constitutional provisions, cases filed in wrong courts in the U.S. are struck out just like in Nigeria ${ }^{7}$. As could be seen, the powers of inter-courts transfer of cases inter se in the U.S. are ably conferred either by statutes, which derived their validity directly from the U.S. Constitution or the U.S. Constitution itself and not left to a whimsical public policy doctrine, rules of court or statutory provisions lacking

\footnotetext{
${ }^{1}$ Nathan S. Chapman and Kenji Yoshino, "Interpretation: The Fourteenth Amendment Due Process Clause| The National Constitution..." at https://constitutioncenter.org "No State shall make or enforce any law which shall abridge the privileges or immunities of citizens of the United States; nor shall any State deprive any person of life, liberty, or property, without due process of law; nor deny to any person within its jurisdiction the equal protection of the laws." See United State v. Shipp, 203 U.S. 563, which relied on the $14^{\text {th }}$ Amendment. See also Professor Douglas O. Linder, "The Trial of Sheriff Joseph Shipp et al.: An Account" at https://famous-trials.com accessed at 12:30pm 30/07/2020. See also Gilbert G. Garcia, "Anniversary of United States v. Shipp: The Only Criminal Trial in Supreme Court History" at https://ggglawfirm.com accessed at 12:19pm 31/07/2020. This case and United States v. United Mine Workers of America U.S.S.C.R. 91 L. ed. 884 at 911 were both cited in Associated Discount House Ltd v. Amalgamated Trustees Ltd (supra) 12 paras. F-G. as given an unqualified power of inter-courts transfer based on public policy. But this view is, with respect, erroneous. Power of inter-courts transfer of cases in the U.S.A. are not based on public policy, as claimed but, are ably conferred by the U.S. Constitution in limited instances, and are strictly limited to the situations clearly and directly permitted by the U.S. Constitution. United States v. Shipps was based directly on the $14^{\text {th }}$ Amendment, likewise United State v. United Mine Workers of America. In all other cases falling outside these exceptions, cases are not transferred but struck out just like in Nigeria. It should even be noted that, the two cases cited by the law lords in Associated Discount House Ltd v. Amalgamated Trustees Ltd (supra) are cases where the Supreme Court of the US intervened in trials at states' courts in the exercise of its supervisory jurisdiction over these courts and did not involve ordering cases wrongly filed in a court without jurisdiction to be transferred to another with the requisite jurisdiction, which is the relevant issue here. So, in effect, these decisions are totally irrelevant to transfer of cases from a court lacking jurisdiction to the one with the requisite jurisdiction.

${ }^{2}$ FindLaw for Legal Professional, "28 U.S.C $\$ 1141$ - U.S. Code - Unannotated Title. Judiciary and Judicial Procedure $\$ 1141$. Removal of Civil actions" at https://codes.findlaw.com accessed 31/07/2020 at 10:38am. See also Jeffrey M. Beyer, "Removal Based on Diversity of Citizenship and the 'Forum Defendant Rule' in 'Removal to Federal Court and the 'Forum Defendant Rule'; Congress Enters 'Snap' Removal Thicket" at https://aw.com accessed 31/07/2020 at 10:57am.

${ }^{3}$ Cornell Law School, "Removal from State Court to Federal Court" at https://law.cornell.edu accessed 10:50am 30/07/2020 at 10:00am. 4 "Federal Removal Jurisdiction, Louisiana Law Review", Vol. 1 | No. 3, March 1939 at https://digitalcommons.law.Isu.edu/cgi/viewcontent.cgi?article=1063\&context=lalrev accessed at 10am 29/07/2020.

${ }^{5}$ Ibid, 502 .

${ }^{6}$ Dean Mostofi, et al v. Capital One, N.A. et al., Case No. RWT 12-cv-2398 at http://www.mdd.uscourts.gov/Opinions/Opions/Mostofi accessed May 72013.

${ }^{7}$ Louisville R.R. v. Motley, 211 U.S. 149, 29 S. Ct. 42; where it was held that, "If any tribunal finds absence of proof of jurisdiction over person and subject matter, the case must be dismissed". See also Vericorr Packaging, LLC v. Osiris Innovations Group, LLC at http://www.mied.uscxourts.gov/Opinions/lawsonpdf/07-12415\%Vericorr\%20... PDF file accessed May 7 2013. The District Court of Eastern District of Michigan dismissed for want of jurisdiction without prejudice a suit that was supposed to be filed at State Court but wrongly filed in the Federal District Court. In Vill. of Oakwood, 481 F. 3d at 366-67, it was held that, "In the absence of jurisdiction, the court's only function is to announce the lack of jurisdiction and dismiss or remand the case", reported on webpage 'Order of Dismissal for Want of Jurisdiction' available at www.mied.uscourts.gov/Opinions/lawsonspdf/07 12415\%20Vericorr\%20... Website visited May 72013.
} 
constitutional backing. It should be noted that, when necessary, the U.S. had to amend its Constitution to accommodate these powers ${ }^{1}$. Though, a court of law in Nigeria is enjoined to create a remedy where none exists in law, and where it comes to the conclusion that, the applicant before it is entitled to some relief or remedy ${ }^{2}$. It is submitted that this, it can only do when it has jurisdiction to entertain the matter, which is quite different from the issue of inter-courts transfer of cases where a court totally lacks jurisdiction over the matter ${ }^{3}$.

\subsection{Case against Reliance on Public Policy Doctrine}

Public policy consideration informed the altruistic observation of the Supreme Court of Nigeria in Associated Discount House Ltd. v. Amalgamated Trustees Ltd [supra] when it opined that, High Courts in Nigeria should be able to transfer cases to the $\mathrm{FHC}^{4}$ by relying on a decision of the U.S. Supreme Court ${ }^{5}$, which ratio decidendi, with the greatest respect, it appears it did not quite appreciate. A close study shows that, this U.S. case cited by the Supreme Court was not based on the doctrine of public policy, as inadvertently imputed by Nigerian Supreme Court, but rather, on a clear constitutional provision ${ }^{6}$. Public policy approach can be successfully challenged on the basis that a court can only exercise any power when it is fully seised of jurisdiction on the cause or matter and not otherwise. Thus, a court must first have jurisdiction before it can rely on public policy to do anything. Where it lacks jurisdiction, it does not have any power ab initio to transfer ${ }^{7}$, except if competently conferred by the Constitution $^{8}$; and if it lacks this power, it cannot confer on itself by invoking the public policy doctrine, power being adjunct of prior jurisdiction. Since the Supreme Court, with the greatest respect, appeared not to adduce any constitutional backing for section 22 of the FHCA, raising purely constitutional issue, it cannot rely on public policy doctrine to justify its legality. The only jurisdiction a court of law has over a matter it lacks jurisdiction is the assumption of the initial jurisdiction to determine if it has jurisdiction or not, nothing more, nothing less ${ }^{9}$. The public policy doctrine can only be invoked where a court has jurisdiction ab initio.

The power exercised by the U.S. Supreme Court in the case under reference was ably conferred, as has been shown, by the U.S. Constitution and not by relying on public policy doctrine being suggested or any rule of court. Since no provision of the Nigerian Constitution can justify the power of inter-courts transfer of cases, then, it cannot be exercised. It has been shown that, in instances not covered by the U.S. Constitution, cases continue to be struck out precisely for the same reasons as in Nigeria. Apart from the fact that the public policy approach smacks of usurpation of legislative functions, there is the grave possibility of its being abused in other non-altruistic instances. "All bad examples', it is said, 'arise from good beginnings ${ }^{10}$." It is therefore felt, with the greatest respect to the law lords that, this public policy approach is totally illegal and unconstitutional and should not be relied on solely in Nigeria to grant a court the power of inter-courts transfer of cases or any power for that matter, where it lacks jurisdiction. The warning of the Supreme Court of Nigeria itself on the dangers inherent in the use of public policy solely by courts to arrive at decisions becomes apposite ${ }^{11}$ :

“...it is dangerous for a court to base its decision mainly on public policy, which indeed would be another means of avoiding the rules, law and procedure which govern a matter. Public policy is usually equated with public good. To ask a court to decide only as a result of public policy or public good, goes beyond the measure of liberalism in the application of the law or even viewing a matter from the socio-economic context of law. ...For while a judge is expected to remain objective, impartial, experienced and full of erudition, these attributes cannot be found in one who seeks total sanctuary for his decision, in public policy. I am not saying that the question of public policy should be wholly excluded. No, it should not. For even then, it is against public policy to produce uncertainty in the law: what I am saying is that public policy is not to be relied upon wholly to fathom a decision, surely, public policy is an unruly horse and judges are not such masters of equestrian ability to take on such experience ... ${ }^{12}$ "

A judge is like the ancient Ifa Priest, with an immutable pact with truth ${ }^{13}$. He pronounced whatever divination

\footnotetext{
${ }^{1}$ Fourteenth Amendment 1868, which allows the Supreme Court of the U.S. to order transfer to itself from any State's Court, cases involving allegations of infraction of the constitutional provisions relating to due process in capital offences.

${ }^{2}$ Oyekanmi v. NEPA (2000) 15 NWLR (Pt. 690) SC 414 at 444, paras. F-G.

${ }^{3}$ Dairo v. Union Bank (supra).

${ }^{4}$ At 649, paras. A-H of Associated Discount House Ltd. v. Amalgamated Trustees Ltd (supra) at 649, paras. A-H.

${ }^{5}$ United States $v$. United Mine Workers of America (supra).

${ }^{6}$ Fourteenth Amendment 1868 and the Judiciary Act.

${ }^{7}$ Jurisdiction cannot be assumed in the interest of justice - see Obiuweubi V. CBN in NWLR (supra) 509, B-E. See also Ajuwa v. S.P.D.C. (Nig.) Ltd (2008) CA 10 NWLR (Pt. 1094) 96, C, F-G; and Uba v. Etiaba \& Ors (2008) LPELR - CA/E/EPT/7/07 (2008) 6 NWLR (Pt. 1067).

${ }^{8}$ See Dairo v. Union Bank (supra); NUEE v. BPE (supra); and Chevron v. Famuye, p. 6, paras. B - C (supra).

${ }^{9}$ Otoakhia v. Aero Contractor Nigeria Limited (2014) LPELR-23319 (CA) 19, B-C.

${ }^{10}$ Machiavelli, N., The Discourse, Penguin Classics, London, 2003 Reprint with corrections, at 224.

${ }^{11}$ Sonnar (Nigeria) Ltd. \& Anor. v. Partenreedri M.S. Nordwind Owners of the Ship M.V. Nordwind \& Anor. (1987) LPELR - 3494 (SC).

${ }^{12}$ Ibid, 27-28, E-G.

${ }^{13}$ Bascom, W., Ifa Divination (1991), Indiana University Press, Bloomington and Indianapolis, First Midland Book Edition, 1991, at 76-77. Ibie, C.O., IFISM: The Complete Work of Orunmila (1986), Efehi Ltd, Lagos, Nigeria at 29-30. Fakayode, F.F., Iwure, Efficacious Prayer to
} 
came out, notwithstanding the implications ${ }^{1}$. Likewise, let the heavens fall, a judge should come to the irresistible conclusion dictated by positive laws. He should not rely on the doctrine of public policy to thwart the dictates of positive laws. Public policies can only be relied upon when and where there is a lacuna and the court has jurisdiction, and never otherwise. Besides, as the issue of inter-courts transfer of cases raises constitutional questions, it is necessary to point out that, the 1999 Constitution is sacred and cannot therefore be treated like an ordinary statute ${ }^{2}$. Its provisions cannot be subjected to the chimerical public policy doctrine, which will make the Constitution liable to the subjective whims and caprices of judges. The Constitution itself, being a statement of the epitome of the public policy of the nation, one needs not go outside it to find what the public policy of the nation is $^{3}$.

Where its provisions are clear, the courts are bound to give them effect, and should not invoke any public policy doctrine outside the Constitution, to negate them ${ }^{4}$. It may be added that, it is even against public policy to encourage subjectivity in the decisions of courts. This will lead to judicial despotism ${ }^{5}$. It is also against public policy to encourage courts to usurp the duties of the legislature, which, apart from its tendency to cause frictions between the two, will ultimately lead the judicature astray and destroy the whole polity ${ }^{6}$. Let the legislature do its job and the judicature its: that is the essence of separation of powers and the bedrock of rule of law. It is considered a better experiment or point of reference to seek to justify powers of inter-courts transfer of cases in Nigeria through reliance on the 1999 Constitution itself than by reliance on a cloudy and subjective doctrine of public policy. Reliance on the Constitution, apart from its objectivity, is better appreciated, readily justifiable and easily justiciable.

It ought to be noted that there is no equivalence of Article 1, Section 8, the last clause therein, which enables the U.S. Congress to grant federal courts removal jurisdiction, in the 1999 Constitution. The near equivalence are the provisions of sections 4(2); 6(6)(c); 17(1) \& (2)(a) \& (c) construed along with item 60(a) of the 1999 Constitution, which gives the National Assembly power to enact law to activate the provisions of Chapter II of the 1999 Constitution, which provides for the fundamental objectives and directive principles of State's policies. Ordinarily, enactment of legislations by the National Assembly to regulate inter-courts transfer of cases could have been justified under these provisions ${ }^{7}$, but for the snag of section 6(6)(a) of the 1999 Constitution, which gives absolute protection for the inherent powers of Nigerian superior courts; and incidentally, the power to strike out cases over which a court lacks jurisdiction is inherent and therefore could not be abrogated under the iron-cast protection afforded it under the 1999 Constitution. There is no equivalence of section 6(6)(a) of the Nigerian extant Constitution in the U.S. Constitution. It follows that no statute could presently validly confer powers of intercourts transfer of cases on the superior courts in Nigeria.

Since this article has examined all the parameters and come to the conclusion that no statute can validly confer powers of inter-courts transfer of cases on the superior courts in Nigeria at present, going by the extant constitutional arrangement, it follows that, the only solution to the problem lies in constitutional alteration. Until then, in spite of the desirability of cases being heard on the merits, cases will continue to be struck out for want of jurisdiction in Nigeria. Having come to this stage, it is apposite to suggest ways of solving the problem.

\section{SUGGESTIONS}

Foremost, section 6(6)(a) of the 1999 Constitution should be altered by removing the phrase "notwithstanding anything to the contrary contained in this Constitution", which has conferred absolute inherent powers on our courts. If this is done, sections 22 and 24 of the FHCA and the NICA respectively will become valid pursuant to section 4 and paragraphs 60 (a), $67 \& 68$ of the of the Exclusive Legislative List of the 1999 Constitution [as altered], which give the National Assembly powers to make the provisions of Chapter II of the 1999 Constitution justiciable ${ }^{8}$. Hence, the powers of inter-courts transfer of cases for lack of jurisdiction will become justiciable pursuant to sections 14(1), 16 -(1)(b) and 17(1), (2)(a), (c) \& (e) of Chapter II of the 1999 Constitution [as altered]. The powers will then become powers validly granted by the National Assembly in pursuit of the social justice objectives of Chapter II of the 1999 Constitution. It will also become possible, as a result of the constitutional alteration, to also place reliance effectively on Articles 7(1) and 13(2) \& (3) of the African Charter on Human and Peoples' Rights [Ratification and Enforcement] Act ${ }^{9}$. In addition to the first suggestion, and in order to take the

Olodumare, the Supreme Force (2011), Ejiodi Home of Tradition, Ibadan, Nigeria at 24-39.

${ }^{1}$ Ibid.

${ }^{2}$ Attorney-General Abia State v. Attorney-General Federation (2006) LPELR - 613 (SC) 201, E-G.

${ }^{3}$ See Chapter II of the 1999 Constitution. See also Scalia, A. and Garner, B.A., Reading Law: The Interpretation of Legal Texts, (2012)

Thomson/West, St. Paul at 33-41.

${ }^{4}$ Ibid.

${ }^{5}$ Rousseau, J. The Social Contract, (1998) Wordsworth Edition Limited, Hertfordshire 1998 Edition at $122-123$.

${ }^{6}$ Ibid.

${ }^{7}$ Olafisoye v. FRN (2004) LPELR-2553 (SC) 67-72, C-D.

${ }^{8}$ Attorney-General of Ondo State v. Attorney-General of the Fedration \& Ors. (2002) LPELR - 623 (SC) 51- 53, E-A.

${ }^{9}$ Cap. A9, LFN, 2004. 
matter outside any possible constitutional objection, an additional provision should be inserted into section 6 of the 1999 Constitution [as altered] to the effect that, 'notwithstanding anything to the contrary contained in this Constitution, the superior courts of record created in section 6 of this Constitution shall each have the power to transfer cases over which each lacks jurisdiction, to the appropriate court with the requisite jurisdiction, instead of striking it out'. This research is of the view that this issue is worth being directly provided for in the Constitution because, the issue of access to justice is central to the well being of citizens and inhabitants of any state; access to justice being the first indicium of humanity and the most pivotal part of the social contract pact.

\section{CONCLUSION}

In closing remarks, the inability of courts to transfer cases over which they lack jurisdiction and the consequential orders striking out such cases in Nigeria, especially when this arises from mid-way divestment of a court's jurisdiction by a statute, is a serious hindrance to the constitutional guarantee of people's right of access to justice in Nigeria. It is opined that, this problem is of such magnitude that it portends grave danger to the commonwealth because, this can only lead to disenchantment with the court system: an invitation to chaos. Attempt has been made to identify the various efforts made to tackle this problem. It has been shown why these attempts have not been fruitful. It has also been shown why, sooner than later, the courts might have to revisit this vexed issue in view of the changes effected by the 1999 Constitution [as altered], which have significant implications for the prior decisions of our courts on this issue. It has also been suggested that only constitutional alteration could give a valid power of inter-courts transfer of cases to our courts.

In concluding this essay, it is submitted that justice cannot be achieved without a guarantee of easy access to it. The attainment of a just society is a duty imposed on modern democratic governments. It is the sustainable cord of the social contract between the governed and the government and between the people inter se $e^{1}$. Any dereliction of government in this behalf is, to say the least, to encourage injustice and people's resort to self helps; which will lead to violence and chaos, and the ultimate destruction of the society itself ${ }^{2}$. The admonition of the Court of Appeal in Mbas Motel Ltd v. Wema Bank Plc ${ }^{3}$ in this respect is very instructive:

"We must never lose sight of the fact that justice is rooted in public confidence and it is essential to social order and security. It is the bond of society and the cornerstone of human togetherness. Justice is the condition in which the individual is able to identify with society, feel at one with it and accept its rulings. The moment members of the society lose confidence in the system of administration of justice, a descent to anarchy begins ${ }^{4} . "$

This treatise is therefore a clarion call on both the Federal and State governments in Nigeria to do all in their powers by effecting the necessary constitutional amendments to reverse this vicious circle of a macabre forwardand-backward dance on an issue as important as life itself, to enhance the nation's attainment of a just and sustainable society. For it is totally unjustifiable to have cases struck out without being heard on merit simply because they were filed in the wrong courts because of the confusions arising from the thin borderlines of exclusive jurisdictions carved out for the superior courts of first instance in Nigeria. And this becomes more indefensible if these cases were filed in the correct courts before the bifurcation of jurisdiction of the courts, because it would mean the litigants were just punished for committing no wrongs!

\section{REFERENCES}

Akande, J.O., Introduction to the Constitution of the Federal Republic of Nigeria, 1999 (2000), MIJ Professional Publishers Ltd, Lagos at 33.

Ayua, I.A., Ayua, I.A., ed., 'Nigerian Legal Profession and Prospects', in Law, Justice and the Nigerian Society: NIALS Commemorative Series 1 (1995) Nigerian Institute of Advanced Legal Studies, Lagos at 1- 20, particularly at 6.

Bascom, W., Ifa Divination (1991), Indiana University Press, Bloomington and Indianapolis, First Midland Book Edition, 1991, at $76-77$.

Bayer, J.M., "Removal Based on Diversity of Citizenship and the 'Forum Defendant Rule' in "Removal to Federal Court and the 'Forum Defendant Rule'; Congress Enters 'Snap'Removal Thicket" at https://law.com accessed $31 / 07 / 2020$ at 10:57am.

Chapman, N.S. and Yoshino K., "Interpretation: The Fourteenth Amendment Due Process Clause| The National Constitution ..." at https://constitutioncenter.org accessed 12:29pm 31/07/2020.

\footnotetext{
${ }^{1}$ Daniel Webster, as quoted in Okoroji O.D., 'Criminal Responsibility and the Inchoate Offence of Conspiracy', NJI Law Journal, (2012) Volume 7, at 166: "Justice is the great interest of man on earth. It is a ligament that holds civilized beings and civilized nations together".

${ }^{2}$ The Frankenstein monster of Boko-Haram in Nigeria has its foundation partly on denial of access to justice in the extra-judicial killing of some of its leaders by the Police - see IRIN Africa, 'Analysis: Understanding Nigeria's Boko Haram radicals', available at http://www.irinnews.org/report/93250/analysis-understanding-nigeria-s-boko-haram-radicals. [Accessed June 6, 2013]

${ }^{3}$ (2013) LPELR - 20736 (CA).

${ }^{4}$ Ibid, 26, E-G.
} 
Cornell Law School, "Removal from State Court to Federal Court" at https://law.cornell.edu accessed 10:50am 30/07/2020 at 10:00am.

Fakayode, F.F., Iwure, Efficacious Prayer to Olodumare, the Supreme Force (2011), Ejiodi Home of Tradition, Ibadan, Nigeria at $24-39$.

Farley, A. 'How to Transfer Court Cases From One State to Another' available at http://www.ehow.com/how_8469875_transfer-cases-o [Accessed May 7, 2013]

FindLaw For Legal Professional, "28 U.S.C $\$ 1141$ - U.S. Code - Unannotated Title. Judiciary and Judicial Procedure \$ 1141. Removal of Civil actions" at https://codes.findlaw.com accessed 31/07/2020 at 10:38am.

Garcia, G.G., "Anniversary of United States v. Shipp: The Only Criminal Trial in Supreme Court History" at https://ggglawfirm.com accessed at 12:19pm 31/07/2020.

Garner, B.A., et al eds., Black's Law Dictionary (1999), West Group, St. Paul Minn. $8^{\text {th }}$ Edition at 825.

Ibie, C.O., IFISM: The Complete Work of Orunmila (1986), Efehi Ltd, Lagos, Nigeria at 29 - 30.

Iriekpen, D., 'Dispute Resolution: Making a Case for ADR' in THISDAY Newspaper (2011) Vol. 16, No. 5826 of Wednesday, April 6, 2011, at. 24

IRIN Africa, 'Understanding Nigeria's Boko Haram radicals' available at http://www.irinews.org/report/93250/analysis-understanding-nigeria-s-boko-haram-radicals. [Accessed June $6,2013]$

Linder, D.O., "The Trial of Sheriff Joseph Shipp et al.: An Account" at https://famous-trials.com accessed at 12:30pm 30/07/2020.

Machiavelli, N., The Discourses, (2003), Penguin Classics, London, 2003 Reprint, at 224.

McLachlin, B., 'Supreme Court of Canada - Beverley McLachlin' available at http://scccsc.gc.ca/court/ju/mclachlin/index-eng.asp [Accessed June 20, 2013].

Moses, E., 'The Continuing Reverberation of the Existing Approach to Determining the Exclusive Jurisdiction of the Federal High Court' in Nigerian Bar Journal (2011), Vol.67 at $1-30$.

Nwabueze, B.O., The Presidential Constitution of Nigeria (1982), C. Hurst \& Company, London at 40.

Okoroji, O.D., 'Criminal Responsibility and the Inchoate Offense of Conspiracy', NJI Law Journal (2012) Vol. 7 at 166.

Udombana, N.J., Azinge E. and Adekunle D. eds. 'Access to Justice and Judicial Attitude to Standing in Nigeria', in Administration of Justice and Good Governance in Nigeria (2011), Nigerian Institute of Advanced Legal Studies, Lagos at $283-322$.

Rousseau, J., The Social Contract (1998), Wordsworth Edition Limited, Hertfordshire, at 122 - 123.

Scalia, A. and Garner, B.A., Reading Law: The Interpretations of Legal Texts (2012), Thomson/West, St. Paul, at $33-41$.

Vanderbilt, A., The Challenges of Law Reform (1955), Princeton University Press, Princeton, at 4 - 5. 